NBER WORKING PAPER SERIES

\title{
GENDER GAPS ACROSS COUNTRIES AND SKILLS: SUPPLY, DEMAND AND THE INDUSTRY STRUCTURE
}

\author{
Claudia Olivetti \\ Barbara Petrongolo \\ Working Paper 17349 \\ http://www.nber.org/papers/w17349 \\ NATIONAL BUREAU OF ECONOMIC RESEARCH \\ 1050 Massachusetts Avenue \\ Cambridge, MA 02138 \\ August 2011
}

We wish to thank Claudia Goldin, Steve Pischke and Gianluca Violante for their suggestions on earlier versions of this paper, and Craig Riddel for invaluable help with the Canadian LFS. We also thank Briana Ballis, Maria Burtseva and Michael Harris for excellent research assistance and the NSF for financial suppport (grant SES-0820127). Helpful comments from seminar participants at Bocconi University, Boston University, the 2009 Summer Meetings of the Econometric Society, the 2009 ESPE Conference, the 2010 Eale/Sole Conference, the 2010 Research on Money and Markets conference and the ESOP-ISF conference on Gender and Households are also gratefully aknowledged. The views expressed herein are those of the authors and do not necessarily reflect the views of the National Bureau of Economic Research.

NBER working papers are circulated for discussion and comment purposes. They have not been peerreviewed or been subject to the review by the NBER Board of Directors that accompanies official NBER publications.

(C) 2011 by Claudia Olivetti and Barbara Petrongolo. All rights reserved. Short sections of text, not to exceed two paragraphs, may be quoted without explicit permission provided that full credit, including (C) notice, is given to the source. 
Gender Gaps across Countries and Skills: Supply, Demand and the Industry Structure

Claudia Olivetti and Barbara Petrongolo

NBER Working Paper No. 17349

August 2011

JEL No. E24,J16,J31

\begin{abstract}
$\underline{\text { ABSTRACT }}$
The gender wage gap varies widely across countries and across skill groups within countries. Interestingly, there is a positive cross-country correlation between the unskilled-to-skilled gender wage gap and the corresponding gap in hours worked. Based on a canonical supply and demand framework, this positive correlation would reveal the presence of net demand forces shaping gender differences in labor market outcomes across skills and countries. We use a simple multi-sector framework to illustrate how differences in labor demand for different inputs can be driven by both within-industry and between-industry factors. The main idea is that, if the service sector is more developed in the US than in continental Europe, and unskilled women tend to be over-represented in this sector, we expect unskilled women to suffer a relatively large wage and/or employment penalty in the latter than in the former. We find that, overall, the between-industry component of labor demand explains more than half of the total variation in labor demand between the US and the majority of countries in our sample, as well as one-third of the correlation between wage and hours gaps. The between-industry component is relatively more important in countries where the relative demand for unskilled females is lowest.
\end{abstract}

Claudia Olivetti

Boston University

Department of Economics

270 Bay State Road

Boston, MA 02215

and NBER

olivetti@bu.edu

Barbara Petrongolo

Centre for Economic Performance

London School of Economics

Houghton Street

London WC2A 2AE

and School of Economics and Finance

Queen Mary University

B.Petrongolo@1se.ac.uk 


\section{Introduction}

Alongside clear advances in the labor market prospects of women over the past few decades, there is evidence of sizable pay and employment disparity still remaining with respect to men in most countries, and the goal of gender equality has recently been stated as one of the Eight U.N. Millennium Development Goals (U.N., 2009).

It is well known that gender pay and employment gaps vary widely across OECD countries (Blau and Kahn, 2003; Olivetti and Petrongolo, 2008). What is probably less known is that there are also large international differences in how gender gaps vary within countries across levels of human capital. For example, in the US, the UK, Nordic countries, Germany and the Netherlands, the gender wage gap is either rising with levels of education, or roughly flat. When moving towards the south of Europe and Ireland, gender wage penalties are largest among the unskilled. Large variations in gender wage gaps are also accompanied by substantial variation in the corresponding gaps in hours worked. In particular, gender gaps in hours everywhere fall with levels of education, but such gradient is highest in southern Europe and Ireland, where employment rates of unskilled women are lowest. This pattern of variation yields a positive cross-country correlation between the unskilled-to-skilled difference in the wage gap and the corresponding difference in the hours gap (see Figure 3). Based on a canonical supply and demand framework, positive co-variation in skill differentials in quantities and prices would not be consistent with international differences in labor supply alone, and reveals instead the presence of net demand forces shaping gender differences in labor market outcomes across skills and countries. Thinking along these lines, the labor demand hypothesis has the potential to explain why the labor market prospects of less-skilled women are more vulnerable in some countries than others.

In this paper we exploit a rich pattern of variation in gender gaps, between- and withincountries, in order to identify gender biases in labor demand across skill groups in a number of OECD countries. Demand forces may have in turn both within- and between-industry components. While within-industry forces reflect differences in gender and skill intensities

within sectors, between-industry forces reflect differences in the sectoral composition of the economy, where different sectors may have different skill and gender intensities. The former may include skill-biased technical change, changes in prices of other inputs, outsourcing, gender comparative advantages, or discrimination. The latter may instead be driven by differences in product demand, in sector-specific productivity growth, in the rate of marketization of home production, or international trade. Building on this decomposition, we link the variation in gender gaps to the process of structural transformation, and investigate whether unskilled women suffer relatively larger labor market penalties in some countries because their female-intensive sectors are relatively less-developed. For example, if the service sector is larger in the US than in southern Europe, and unskilled women tend to be over- 
represented in services, we expect unskilled women to suffer a relatively large wage and/or employment penalty in the latter than in the former.

We use micro data that are as comparable as possible across countries, namely the US Current Population Survey, the Canadian Labor Force Survey, and the European Community Household Panel Survey, in order to obtain a measure of net demand differences by gender and levels of education. Our first result is that everywhere except in the UK, Germany and the Netherlands, there is a stronger gender bias in the demand for unskilled than skilled labor, relative to the US. That is, the demand for unskilled female labor is relatively higher in the US than in most countries in our sample. This finding cannot be explained by crosscountry differences in the process of women's selection into paid employment, as we obtain very similar results when we correct observed wages for sample selection. We also provide suggesting evidence that cross-country variation in gender gaps is not driven by institutional or cultural factors that may affect the relative demand and supply of female labor differently across skill groups and countries, as the partial correlation between gender gaps in quantities and prices remains firmly positive when we control for a number of institutional and cultural indicators.

Based on a simple model of a multi-sector economy, we illustrate how the variation in the male bias in labor demand may be driven by cross-country differences in labor input intensities within industries, or differences in product demand across industries with different input intensities. Using a ten-fold industry classification, we decompose differences in labor demand between each country in our sample and the US into within- and between-industry components, and find that both play important roles in explaining international differences in labor demand, with wide variation in their relative importance across countries.

For realistic values of the elasticity of substitution between male and female labor inputs, the between-industry component explains more than a half of the demand differential with respect to the US in the majority of countries, and namely Nordic countries, the Netherlands, Austria, Ireland, France and southern Europe. This result is mostly driven by the different weight of the broad service sector between these countries and the US. The interpretation is that the service sector in the US is larger than in other countries, and in this sector the unskilled gender bias in labor demand is smaller than the skilled one. In the remaining countries, there is either a smaller gender bias in the demand for unskilled than skilled labor relative to the US, or the within-industry component of labor demand differences largely dominates the between-industry one. In other words, the between-industry component tends to be relatively more important in cases where the demand for unskilled females is relatively low. Finally, adjusting unskilled-to-skilled wage gaps across countries for the between-industry component of labor demand reduces the corresponding correlation with hours gaps by two thirds, from 0.41 to 0.14 .

The within-industry component of labor demand differences is also sizable in most coun- 
tries, as most sectors in the US tend to be more unskilled-women intensive than elsewhere. In particular, we find that international differences in the occupational structure within industries drive a large fraction of the within-industry component of labor demand. This is not surprising. For example, if the manufacturing sector is more unskilled-female intensive in the US than in other countries, then this sector also tends to have an occupational structure that is relatively more favorable to unskilled women in the US than in other countries.

By looking at the role of the industry structure in shaping gender gaps across skills and countries, this paper brings together two strands of literature. First, there exists a literature on the driving forces of the international variation in the gender gap. Our previous work (Olivetti and Petrongolo, 2008) stresses that, if there is overall positive selection into employment, employed women tend to have relatively high-wage characteristics. Thus low female employment rates become consistent with low wage gaps simply because low-wage women are less likely to feature in the observed wage distribution. Work by Blau and Kahn (1996, 2003) emphasize the role of international differences in overall inequality: if women tend to have on average lower wage characteristics than men, higher overall inequality would translate such differences into a wider gender pay gap. We contribute to this literature by uncovering the skill dimension of gender inequalities, relating the variation in gender gaps across skills and countries to demand and supply forces.

Second, this paper is related to a large literature on the labor market impact of structural transformation. In the micro literature, seminal work by Katz and Murphy (1992) shows that an important fraction of changes in the US wage distribution from 1963 to 1987 can be explained by a within-sector rise in demand for skilled labor, in turn led by increasing computerization of production processes (Autor, Katz and Krueger, 1998). More recently, Autor, Levy and Murnane (2003) propose a task-based view of technological progress, having conceptualized work as a series of tasks that can be classified into routine or non-routine activities, and Autor and Dorn (2009) show how recent employment and wage polarization in the US might have been driven by the reduced usage of routine tasks following the adoption of new technologies. ${ }^{1}$ In the macroeconomic literature, Ngai and Pissarides (2008) illustrate how long-run trends in aggregate market hours in the US are related to the secular decline of agriculture and the rise of services, and Rogerson (2008) relates differences in market hours between continental Europe and the US to the smaller weight of the service sector in European economies. Both papers highlight the marketization of services that have home substitutes as a key force driving structural transformation and variation in market hours.

Our approach complements existing micro and macro studies along two main dimensions. First, we introduce gender and skill dimensions in the analysis of the labor market effects

\footnotetext{
${ }^{1}$ See Goos and Manning (2007) for a study of polarization in the UK labor market, and Goos, Manning and Salomons (2010) for an application to a number of European countries. See also Black and Spitz-Oener (2010), for a study of the impact of routinization on the gender wage gap in West Germany.
} 
of structural transformation. If skilled and unskilled women tend to be over-represented in different industries, special attention should be paid to the impact of the industry structure on female labor market outcomes across the skill distribution. Second, we emphasize international differences in both gender gaps and the industry structure, and illustrate the role of the between-industry component of labor demand in shaping international variation in the gender gap.

The paper is organized as follows. Section 2 describes our data sets and provides evidence on the variation of gender gaps across skills and countries, highlighting the presence of net demand forces underlying such variation. Section 3 proposes a simple theoretical framework that illustrates the relationship between gender gaps across skills and gender biases in labor demand. Section 4 shows that international variation in employment selection, institutions or cultural norms fails to explain the observed correlations between hours and wage gaps, while variation in the share of services may have a better potential at that. Section 5 generalizes our theoretical framework to a multi-sector economy in which differences in labor demand can be decomposed in measurable within- and between-industry components. Section 6 presents our decomposition results and shows that the between-industry component explains an important portion of the total variation in labor demand between the US and the majority of countries in our sample, as well as of the evolution of cross-country differences between 1970 and 2000. Section 7 concludes.

\section{Some preliminary evidence}

In this section we present descriptive evidence on gender gaps by levels of education for the US, Canada and thirteen European countries. These are: UK, Finland, Denmark, Germany, Netherlands, Belgium, Austria, Ireland, France, Italy, Spain, Portugal and Greece. For the US we use data from the March Current Population Survey (CPS) for the years 19952002, where each year's survey contains detailed information on the previous year's labor market variables. This choice of sample period is made to ensure consistency with European data, extracted from the European Community Household Panel Survey (ECHPS), which is only available from 1994-2001 and provides contemporaneous information on labor market variables. For Canada we use data from the march Labor Force Survey (LFS) for the years 1997-2004. Questions on wages and earnings are first included in the Canadian LFS in 1997, and in order to use eight survey years for Canada as for most other countries we extend the Canadian sample until 2004.

While the data are quite different in structure - for the US and Canada we use repeated cross-sections, for Europe we have an unbalanced panel - the information we exploit from these data is as consistent as possible across countries. We select individuals ages 25-54 who

are not in full-time education, retired, military, or self employed, and use information on 
gender, age, educational qualifications, industry, occupation, weekly hours and wages.

Weekly hours are obtained for the US as total annual hours in the previous year, divided by the number of weeks worked. For Canada and Europe, we use information on usual hours in the survey week. This allows for a more consistent measure of working hours across countries, as the information on current hours in the CPS refers to actual rather than usual hours. Hourly wages are obtained for the US as gross wage and salary income in the previous year, divided by annual hours worked. For Canada, we use information reported on gross hourly earnings. For Europe, wages are obtained by dividing current gross monthly wage and salary earnings by actual hours worked, as we do not have a measure of usual earnings in the ECHPS. Our core sample includes individuals with positive earnings and non zero hours. As the definition as well as the adoption of part-time work varies widely across countries, we do not restrict the analysis to full-time workers.

Information on educational attainment is only available in the ECHPS by broad categories, i.e. less than upper secondary high school, upper secondary school completed, and higher education. These correspond to ISCED 0-2, 3, and 5-7, respectively. We thus attempt to reproduce this threefold distinction for the US and Canada, where available categories of education are 15 and 7, respectively. For the US, the low education group includes all individuals who have not completed 12 th grade, the middle group includes those who have completed 12 th grade but do not have a college degree, and the high-education group includes those who have completed a college degree. For Canada the three categories include those who have not completed secondary education, those who have completed upper secondary education but do not have a college degree, and those with a college degree, respectively. Education shares in the population for each country are reported in Table A1.

Our analysis below is focused on a two-fold distinction between skilled and unskilled, so one would need to somehow reorganize the three educational categories available into two groups. An obvious solution would be to merge the mid-education group to either the lowor high-education group. This is equivalent to treating secondary school graduates as either pure non-graduate equivalents or pure college equivalents. A method to illustrate which one of these two options is more appropriate consists in using wage regressions to determine the extent to which the wages of high school graduates co-move with the wages of non-graduates and college graduates, respectively, as also performed in Katz and Murphy (1992). We thus regress mean wages for high school graduates by year, country and gender on mean wages for dropouts and college graduates, plus controls for year, country and gender. The regression results show that a person with a high school degree is equivalent to a total of 0.984 of a person without a school diploma (with a standard error of 0.061), and -0.014 of a person with a college degree $($ s.e. $=0.029)$. We thus merge the low- and middle-education groups to form our unskilled labor group, and the skilled group is represented by college graduates. This classification also has the advantage to define as skilled a group whose qualifications 
are measured relatively consistently across countries.

Figure 1 shows cross country variation in the gender wage gap for the skilled and the unskilled. The values represented in the bar chart are obtained as coefficients on a male dummy in regressions for log hourly wages that only control for gender and year effects, using population weights. All estimates are significantly different from zero at the 1 percent significance level. In Nordic countries and a group of continental European countries including Germany, Netherlands, Austria and France, the gender wage gap is higher for the skilled than for the unskilled, though it can be noted that the proportional difference is stronger in Nordic countries than in other countries. In the rest of the sample the wage gap is instead higher for the unskilled than for the skilled. While in the US such difference is rather small, at least in proportional terms, it becomes quite sizable in other countries, and especially in Canada, Ireland, Italy and Greece. Although the correlation is far from perfect, countries with low average wage gaps are also countries in which the wage gap tends to fall with years of education.

Figure 2 presents corresponding information for gender gaps in working hours. The values displayed are the gender difference in the (log of the) hours to population ratio, where hours are obtained as the sum of usual weekly hours by gender, skill and country, and the population is the corresponding head count. In all countries except Finland the gender gap in hours worked falls substantially with the level of education, but the gradient is much stronger in Belgium, Ireland and Southern Europe than elsewhere.

This rich variation in gender gaps can be broadly summarized by looking at the correlation between the skill differential in the wage and hours gaps. In Figure 3 we plot the difference between the unskilled and the skilled wage gap (i.e. the difference between each couple of country bars in Figure 1) against the difference between the unskilled and the skilled hours gap (i.e. the corresponding difference from Figure 2). The correlation between them is positive, equal to 0.41 . There is clearly no outlier country that drives this correlation, and excluding each country in turn from the sample we obtained correlation estimates ranging from 0.32 (excluding Finland) to 0.52 (excluding Canada). Thus despite some variation in the correlation obtained across different samples, its range of variation remains firmly positive. Positive co-movements of quantity and price differentials presented here points in the direction of demand factors possibly shaping the variation in gender gaps across skills and countries. The next section more formally models gaps in labor demand and supply for an economy with CES technology, and works out implications for wage and hours gaps.

\section{A simple theoretical illustration}

Let's consider an economy that produces output $Q$ employing a combination of skilled and unskilled labor, denoted by $S$ and $U$ respectively, according to the following CES production 
function:

$$
Q=\left[\alpha S^{\rho}+(1-\alpha) U^{\rho}\right]^{1 / \rho},
$$

where $\alpha$ is a technology parameter representing the relative weight of skilled labor in output production. The elasticity of substitution between skilled and unskilled labor is given by $\bar{\sigma}=1 /(1-\rho)$, with $\rho \leq 1$.

The economy is populated by male and female workers, indexed by $M$ and $F$ respectively, who can be either skilled or unskilled. We assume that skilled and unskilled labor inputs are both described by CES aggregators of female and male labor:

$$
\begin{aligned}
S & =\left[\beta_{S}\left(B_{M S} M_{S}\right)^{\rho_{S}}+\left(1-\beta_{S}\right)\left(B_{F S} F_{S}\right)^{\rho_{S}}\right]^{1 / \rho_{S}} \\
U & =\left[\beta_{U}\left(B_{M U} M_{U}\right)^{\rho_{U}}+\left(1-\beta_{U}\right)\left(B_{F U} F_{U}\right)^{\rho_{U}}\right]^{1 / \rho_{U}},
\end{aligned}
$$

where $M_{S}, M_{U}, F_{S}$ and $F_{U}$ represent the four types of labor inputs, $B_{M S}, B_{M U}, B_{F S}$ and $B_{F U}$ are the associated labor-augmenting technological parameters, and $\beta_{S}$ and $\beta_{U}$ index the share of work activities performed by men from each skill group. Finally, $\rho_{S}$ and $\rho_{U}$ determine the elasticity of substitution between male and female labor in each skill group according to $\sigma_{S}=1 /\left(1-\rho_{S}\right)$ and $\sigma_{U}=1 /\left(1-\rho_{U}\right)$, respectively.

Under perfect competition in the labor market, all inputs are paid their marginal productivity, and thus the gender wage ratio of skill $i=S, U$ is given by:

$$
\frac{W_{M i}}{W_{F i}}=\frac{\beta_{i}}{1-\beta_{i}}\left(\frac{B_{M i}}{B_{F i}}\right)^{\left(\sigma_{i}-1\right) / \sigma_{i}}\left(\frac{M_{i}}{F_{i}}\right)^{-1 / \sigma_{i}},
$$

where $W_{M i}$ and $W_{F i}$ denote real wages. Taking logs we obtain:

$$
\Delta w_{i}=\widetilde{\beta}_{i}-\frac{1}{\sigma_{i}} \Delta h_{i},
$$

where $\Delta w_{i}=\ln \left(\frac{W_{M i}}{W_{F i}}\right)$ and $\Delta h_{i}=\ln \left(\frac{M_{i}}{F_{i}}\right)$ are the skill-specific gender gaps in wages and hours respectively, while $\widetilde{\beta}_{i} \equiv \frac{1}{\sigma_{i}}\left\{\sigma_{i} \ln \left[\beta_{i} /\left(1-\beta_{i}\right)\right]+\left(\sigma_{i}-1\right) \ln \left[B_{M i} / B_{F i}\right]\right\}$ denotes the skill-specific gender bias in labor demand.

Given the gender wage gap in (4), and assuming that elasticities of substitution between male and female labor are constant across skills $\left(\sigma_{S}=\sigma_{U}=\sigma\right)$, one can obtain the withincountry skill difference in gender wage gaps as:

$$
\Delta w_{U}-\Delta w_{S}=\left(\widetilde{\beta}_{U}-\widetilde{\beta}_{S}\right)-\frac{1}{\sigma}\left(\Delta h_{U}-\Delta h_{S}\right) .
$$

The within-country variation in wage gaps across skill levels is thus driven by both differences in relative demand for each skill group $\left(\widetilde{\beta}_{U}-\widetilde{\beta}_{S}\right)$ and differences in relative supplies $\left(\Delta h_{U}-\Delta h_{S}\right)$.

Finally, we are interested in how the double difference in (5) varies across countries. To ease this comparison, assume for simplicity that elasticities of substitution between male and 
female labor inputs are constant across both countries and skills, and denoted by $\sigma$, and that the only factors that vary across countries are relative demands and supplies of labor inputs. Thus the (triple) difference in wages across genders, skills and countries can be expressed as

$$
\Delta_{C}\left(\Delta w_{U}-\Delta w_{S}\right)=\Delta_{C}\left(\widetilde{\beta}_{U}-\widetilde{\beta}_{S}\right)-\frac{1}{\sigma} \Delta_{C}\left(\Delta h_{U}-\Delta h_{S}\right),
$$

where $\Delta_{C}$ indicates the differential between a generic country $C$ in our sample and the US.

Equation (6) helps us clarifying our interpretation of Figure 3. Let's imagine $\Delta_{C}\left(\widetilde{\beta}_{U}-\widetilde{\beta}_{S}\right)=$ 0 , i.e. relative demand for labor inputs does not vary across countries. In this case equation (6) implies a negative cross-country relationship between $\left(\Delta w_{U}-\Delta w_{S}\right)$ and $\left(\Delta h_{U}-\Delta h_{S}\right)$, with a slope equal to the inverse of the elasticity of substitution. In fact, the positive relationship that we observe in Figure 3 can only be rationalized by underlying net relative demand differences. Before exploring the nature of cross-country differences in labor demand, the next section will consider a few caveats to a demand-story interpretation of the observed variation in gender gaps.

\section{Sample selection, institutions and culture}

A rich variety of factors may in principle drive the correlation between wage and hours gaps and, especially when cross-country differences are considered, an obvious culprit would be variation in institutions or something as broad as "social norms". One may think that institutions such as maternity leave legislation can potentially affect relative demand and supply of female labor, and if responses are skill specific, they may affect the cross country variation of gender gaps by skill. Similarly, culture and the perceived role of women in society may vary across countries and skill groups.

We will assess the role of these factors in two ways. First, to the extent that institutions and social norms have an impact on women's (and possibly men's) participation into paid employment, we will control for different patterns of employment selection across countries and skills. Second, we will directly look at partial correlations between wage and hours gaps, having controlled for (available indices of) attitudes towards female work and labor market institutions at the country level.

Concerning selection, it should be noted that the demographic groups considered are indeed characterized by very different employment rates. In particular, gender gaps in employment to population ratios vary from less than 10 percentage points in some cases in our sample, to nearly 60 percentage points in others. Thus it makes sense to worry about the way in which different pattern of employment selection across genders, skills and countries may affect our results, if at all. ${ }^{2}$

\footnotetext{
${ }^{2}$ Blau and Kahn (2006) and Mulligan and Rubinstein (2008) find that employment selection mechanisms
} 
Specifically, we relate the observed positive association between wage and hours gaps to underlying differences in labor demand, but one could think of alternative mechanisms that would drive similar correlation patterns, based for example on different social norms driving different patterns of employment selection across countries. Imagine, for the sake of the argument, that in southern Europe it would be socially acceptable for an educated woman to take a skilled job, but it would not seem proper for an uneducated woman to take an unskilled job as a cleaner or waitress, unless she is 'forced' by economic conditions in her household. As a result, fewer uneducated women would work, and those who work would be negatively selected, i.e. they may be married to relatively low-wage husbands, and would have low-wage characteristics themselves, resulting in higher wage gaps at the bottom of the wage distribution. This hypothetical outcome, although observationally equivalent to some of the patterns observed in Figures 1 and 2, would not be driven by differences in demand forces, but simply by differences in the quality composition of the employed workforce in different countries. Below we thus assess the impact of employment selection mechanisms on the observed correlations between wage and hours gaps.

We use a very simple method for controlling for selection, that is we impute wages to the nonemployed based on their observable characteristics, and then estimate median wage gaps on the resulting enlarged wage distribution. ${ }^{3}$ By relying on median, as opposed to mean, wage gaps, the only information that is exploited about imputed wages is their position with respect to the median of the potential wage distribution, not the actual imputed level. Our imputation follows two alternative rules. With the first rule, we impute wages below the median (by gender and skill) to all those who are unemployed, as opposed to nonparticipants, and we leave the potential wages of nonparticipants as missing. The underlying idea is that the unemployed are receiving wage offers (if any) below their reservation wage, while the employed have received at least one wage offer above their reservation wage. At given reservation wages, the unemployed have lower potential wages than the observed wages of the employed, and are thus assigned an imputed wage below the median. With the second rule, we assign wages below the median to non working individuals whose partners have

can explain part of the evolution of the gender wage gap in the US over time, and our previous work (Olivetti and Petrongolo, 2008) has emphasized the importance of employment selection in interpreting international differences in gender wage gaps. None of these studies, however, investigate the role of selection along the skill dimension.

${ }^{3}$ An even simpler way to deal with sample selection would be to control for the observed characteristics of the employed population when estimating pay gaps. As our groups are already defined along gender and education dimensions, the obvious further control to be considered would be age, as a proxy for labor market experience. We thus estimated gender pay gaps having controlled for age and age squared in the corresponding regressions (as well as for time effects), and obtained a correlation between the unskilled to skilled difference in the adjusted pay gaps and the corresponding difference in the hours gap equal to 0.66. Controlling for age actually raises - rather than explain - the observed correlation between gender pay and employment gaps. In other words, the implied differences in labor demand forces would be even stronger if we were controlling for differences in the average age of gender/skill groups across countries. 
total income in the bottom quartile of their gender/skill-specific distribution, based on the assumption of assortative mating along wage attributes. ${ }^{4}$

Figure 4 shows scatter plots of gender gaps using selection-corrected median wages. In panel A wage imputation is based on unemployed versus nonparticipant status, while in panel B it is based on spouse income. The two panels give almost identical results, i.e. the correlation between wage and employment gaps stays firmly positive once we control for selection into paid work. If anything, such correlation is higher than when we use uncorrected wage gaps in Figure 3. Hence we find no evidence at all that employment selection behavior may explain the observed variation of gender gaps by skill.

We next look at how the partial correlation between the skill differential in wage gaps and the skill differential in hours gaps is affected if one controls for institutional or cultural indicators. Such correlations are reported in Table 1, with the associated $p$-values. In column 1 no other controls are included, corresponding to the exercise represented graphically in Figure 3, and the correlation between the two variables is positive and significant at the 10 percent level. Columns 2-4 control for three institutional variables in turn, and namely: (i) the generosity of maternity leave legislation, which may affect both demand and supply of female skills; (ii) a measure of the marginal tax rate for second earners, which would predominantly affect the labor supply behavior of (unskilled) women; and (iii) the strictness of employment protection legislation, which may affect demand for high-turnover workers relative to others. In columns 2 and 3 the correlation between wage and hours gaps is only slightly reduced with respect to column 1 , while in column 4 it somewhat increases. While these institutional factors may affect the relative labor market position of skilled and/or unskilled women (and we will not expand further on these effects here), the point these partial correlations make is that there is some residual labor demand story that shapes observed skill/gender differentials.

Columns 5-8 control for indexes of women's and men's attitudes towards traditional gender roles. Column 5 controls for the proportion of women who agree with the statement: "When jobs are scarce, men should have more right to a job than women", and column 6 controls for the corresponding proportion of men. Columns 7 and 8 control for the proportion of women and men, respectively, who agree with the statement "Being a housewife is just as fulfilling as working for pay". None of these variables can wash away the positive correlation between wage and hour gaps. In fact such correlation tends to be considerably higher in columns 6 and 8 than in column 1, and is always significant (at least) at the 10 percent level.

\footnotetext{
${ }^{4}$ See Olivetti and Petrongolo (2008) for a discussion of the theoretical underpinnings of this methodology. Our preferred selection correction method in that paper consisted in imputing wages to the nonemployed in some base year using wage observations from adjacent waves in panel data. Here we are unable to follow this approach. The reason is that for the US and Canada we do not have panel data, and for European countries the overall sample size is relatively small, and thus we need to pool all waves in the panel in order to be able to work on cells defined by gender, skill, industry and country.
} 
Columns 9-10 control for wage bill shares in various sectors in the economy, proxying for the between-industry component of labor demand. While the wage bill shares of the primary, manufacturing and construction sectors if anything raise the partial correlation between gender wage and hours gaps, this becomes negative as soon as the share of six broad services sectors is controlled for. Moreover, controlling for the weight of service sectors help explain two thirds of the overall cross-country variation, giving the highest $R^{2}$ across specifications in this table. Finally, column 11 controls for the IT capital share in total capital compensation, which may affect demand for skills and genders within industries. This reduces the correlation between gender wage and hours gaps in both size and statistical significance, but it remains positive.

Of course the list of variables considered is not exhaustive, and given the basic specification and small sample size one should take these correlations with more than some caution, but one could very simply relate the evidence reported in Table 1 to the relationship between pay gaps, hours gaps and demand forces, as represented in equation (6). Only if one were

able to properly account for demand differences across countries, $\Delta_{C}\left(\widetilde{\beta}_{U}-\widetilde{\beta}_{S}\right)$, would the the partial correlation between wage and hours gap turn negative. Table 1 has shown that a number of institutional or cultural factors would not be able to account for such demand differences, while the weight of services in the economy seem to do a better job at that. Taking stock of these pieces of evidence, the next section explicitly introduces a sectoral dimension into a simple model for labor demand.

\section{A multisector economy}

Differences in labor demand across genders, skills and countries may have both within- and between-industry components. The within-industry component reflects differences in gender or skill intensities that happen within sectors. These are typically attributed to non-neutral technological progress, changes in prices of other inputs, gender comparative advantages, or taste and/or statistical discrimination. Between-industry forces reflect changes in the sectoral composition of the economy, where different sectors may have different skill and gender intensities. These may stem from differences in product demand, differences in sectorspecific productivity growth, in the rate of marketization of home production, or international trade. Among all these, factors that will be relevant for our analysis are those that can drive cross-country differences between high- and low-skill gender gaps.

\subsection{Shift share analysis}

Following this distinction, we can decompose the difference between the wage bill share of a given factor $k(k=M S, M U, F S, F U)$ between each country and the US into a term 
reflecting differences in labor allocation across sectors, and a term reflecting differences in gender and skill intensities within sectors. In what follows we denote wage bill shares by lower case $y$ and wage bills by upper case $Y$, and index by 0 the reference country (US) and by $C=1, \ldots, 14$ other countries in the sample. Thus the difference in wage bill shares of input $k$ between country $C$ and the US can be expressed as

$$
y_{k C}-y_{k 0}=\sum_{j} \gamma_{k j}\left(\frac{Y_{j C}}{Y_{C}}-\frac{Y_{j 0}}{Y_{0}}\right)+\sum_{j} \gamma_{j}\left(\frac{Y_{k j C}}{Y_{j C}}-\frac{Y_{k j 0}}{Y_{j 0}}\right),
$$

where $j$ indexes sectors, $Y_{k j C}$ denotes the wage bill of input $k$ in sector $j$ in country $C$, $Y_{j C}=\sum_{k} Y_{k j C}$ denotes the sectoral wage bill, $Y_{C}=\sum_{j} Y_{j C}$ denotes the aggregate wage bill and finally $\gamma_{k j}=\left(\frac{Y_{k j C}}{Y_{j C}}+\frac{Y_{k j 0}}{Y_{j 0}}\right) / 2$ and $\gamma_{j}=\left(\frac{Y_{j C}}{Y_{C}}+\frac{Y_{j 0}}{Y_{0}}\right) / 2$ are decomposition weights. No time subscripts are used as all magnitudes are averages for the period 1994-2001, or a subsample of this if not all waves are available. The first term in equation (7) represents the cross-country difference in the wage bill share of input $k$ that is attributable to differences in the size of industries that employ input $k$, while the second term reflects cross-country differences in input- $k$ intensities within industries. The $\gamma_{k j}$ and $\gamma_{j}$ terms serve as weights on the between- and within industry components, respectively, obtained as cross country averages.

While the cross-industry variation is the main dimension through which we analyze crosscountry differences in this study, the above decomposition can be used to look into other dimensions of the structure of labor demand. In particular, one may be interested in the role of the occupational structure in shaping labor demand patterns across countries, and this links to a growing "task-based" approach to changes in labor demand, which focuses on the impact of technological change on the occupational structure (see Autor, Levy and Murnane, 2003, and Acemoglu and Autor, 2011, for a comprehensive review of the subsequent literature). As changes in the occupational structure may take place within industries, one can further decompose the within-industry component in (7) into a between-occupation and a within-occupation component, according to the following expression:

$$
\begin{aligned}
y_{k C}-y_{k 0}= & \sum_{j} \gamma_{k j}\left(\frac{Y_{j C}}{Y_{C}}-\frac{Y_{j 0}}{Y_{0}}\right) \\
& +\sum_{j} \gamma_{j}\left[\sum_{q} \gamma_{k j q}\left(\frac{Y_{j q C}}{Y_{j C}}-\frac{Y_{j q 0}}{Y_{j 0}}\right)+\sum_{j} \gamma_{j q}\left(\frac{Y_{k j q C}}{Y_{j q C}}-\frac{Y_{k j q 0}}{Y_{j q 0}}\right)\right],
\end{aligned}
$$

where the first term is the usual between-industry component as in (7), and the second term highlights between- and within-occupations components, with occupations being indexed by $q$. The $\gamma_{k j q}$ and $\gamma_{j q}$ are decomposition weights, and specifically $\gamma_{k j q}=\left(\frac{Y_{k j q C}}{Y_{j q C}}+\frac{Y_{k j q 0}}{Y_{j q 0}}\right) / 2$ and $\gamma_{j q}=\left(\frac{Y_{j q C}}{Y_{j C}}+\frac{Y_{j q 0}}{Y_{j 0}}\right) / 2$, where $Y_{k j q C}$ represents wage bills by group, industry, occupation and country, and $Y_{j q C}$ represents wage bills by industry, occupation and country. 


\subsection{A multisector model of labor demand}

Before quantifying the components of the shift-share decomposition above, we incorporate such decomposition into a multi-sector model of labor demand. This will help link the variation in labor demand to cross-country differences in the strenght of the male-bias in each industry or to differences in product demand across industries with different gender and skill intensities.

Following the standard approach in this literature, ${ }^{5}$ we consider an economy with $J$ industries, and assume that output in each industry $j, Q_{j}$, is produced combining skilled and unskilled labor according to a CES production function like (1), with constant elasticity of substitution across sectors, denoted by $\bar{\sigma}=1 /(1-\rho){ }^{6}$

In our model skilled and unskilled labor inputs are further CES aggregators of male and female labor according to equations (2) and (3), respectively, with constant elasticities of substitution $\sigma_{i}=1 /\left(1-\rho_{i}\right)$, but with sector-specific technology parameters $\beta_{i j}, B_{M i j}$ and $B_{F i j}$, implying that the various labor inputs are not equally productive across sectors. Aggregate output is given by $Q=\sum_{j} A_{j} Q_{j}$, where $A_{j}$ denotes total factor productivity in industry $j$.

The relative demand for the output of industry $j$ relative to a reference industry $r$ is assumed to be given by the unit price elasticity function

$$
\frac{Q_{j}}{Q_{r}}=\theta_{j} P_{j}
$$

where $P_{j}$ denotes the price of $Q_{j}$ relative to $Q_{r}$ and $\theta_{j}$ is a demand shifter that reflects consumer tastes, international trade and other factors affecting relative product demand for the output of industry $j$.

For the special case of a Cobb-Douglas economy $\left(\bar{\sigma}=\sigma_{S}=\sigma_{U}=1\right)$, it can be shown that under the assumptions of perfect competition and perfect mobility in the labor market the gender wage gap for skill group $i$ is given by:

$$
\Delta w_{i}=\widetilde{\beta}_{i}-\Delta h_{i}
$$

which is equivalent to expression (4) of the aggregate economy, with $\sigma_{i}=1$ and the qualification that

$$
\widetilde{\beta}_{i}=\ln \left(\frac{\sum_{j} \beta_{i j} \theta_{j}}{\sum_{j}\left(1-\beta_{i j}\right) \theta_{j}}\right)
$$

is now a function of the different skill intensities within industries $\left(\beta_{i j}\right)$ and consumer's demand across industries $\left(\theta_{j}\right)$. This highlights the within- and between-industry components, respectively, in the gender bias in labor demand.

\footnotetext{
${ }^{5}$ See Katz and Autor (1999).

${ }^{6}$ This assumption, that is common in this literature, is made for empirical tractability, see Bound and Johnson (1992, footnote 7).
} 
The next step consists in measuring the quantities of interest for our decomposition. Given (10), the total cross-country difference in the gender bias in labor demand is given by the log difference in wage bill shares. That is, denoting by $\Delta_{C} \widetilde{\beta}_{i}$ the cross-country difference in $\widetilde{\beta}_{i}$, (10) implies

$$
\Delta_{C} \widetilde{\beta}_{i}=\Delta_{C} \ln y_{M i}-\Delta_{C} \ln y_{F i}
$$

Turning to between- and within-industry components, the assumption of Cobb-Douglas preferences and technology throughout this economy allows us to measure the $\beta_{i j}$ terms of equation (11) as wage bill shares of a given input in industry $j$, and the $\theta_{j}$ terms as shares of total revenue accruing to an industry $j$, having normalized $\sum_{j} P_{j} Q_{j}=1$. That is, $\beta_{i j}=Y_{M i j} / Y_{j}$ and $\theta_{j}=Y_{j} / Y$, implying that cross-country differences in $\widetilde{\beta}_{i}$ can be decomposed in simply measurable within- and between-industry components. These are shown to be (approximately) equal to:

$$
\Delta_{C} \widetilde{\beta}_{i}^{\text {between }}=\ln \left(1+\frac{\sum_{j} \frac{Y_{M i j C}}{Y_{j C}}\left(\frac{Y_{j C}}{Y_{C}}-\frac{Y_{j 0}}{Y_{0}}\right)}{y_{M i 0}}\right)-\ln \left(1+\frac{\sum_{j} \frac{Y_{F i j C}}{Y_{j C}}\left(\frac{Y_{j C}}{Y_{C}}-\frac{Y_{j 0}}{Y_{0}}\right)}{y_{F i 0}}\right)
$$

and

$$
\Delta_{C} \widetilde{\beta}_{i}^{\text {within }}=\ln \left(1+\frac{\sum_{j} \frac{Y_{j C}}{Y_{c}}\left(\frac{Y_{M i j C}}{Y_{j C}}-\frac{Y_{M i j 0}}{Y_{j 0}}\right)}{y_{M i 0}}\right)-\ln \left(1+\frac{\sum_{j} \frac{Y_{j C}}{Y_{c}}\left(\frac{Y_{F i j C}}{Y_{j C}}-\frac{Y_{F i j 0}}{Y_{j 0}}\right)}{y_{F i 0}}\right)
$$

respectively. ${ }^{7}$ These two expressions can be evaluated using the between- and within-industry components from our shift-share analysis and the data on the wage-bill share by demographic group (reported in Table A2). In particular, all terms in the numerators in (13) and (14) are obtained as terms of the shift share decomposition illustrated in equation (7).

The above framework can be generalized by representing $S_{j}$ and $U_{j}$ as CES aggregators of male and female labor, with a skill-invariant elasticity of substitution $\sigma_{S}=\sigma_{U}=\sigma$, while keeping demand for industry output and sector-level technology as Cobb-Douglas. In this case, the total cross-country difference to be explained is

$$
\Delta_{C} \widetilde{\beta}_{i}=\Delta_{C} \ln y_{M i}-\Delta_{C} \ln y_{F i}+(\sigma-1) \Delta_{C} \Delta w_{i}
$$

where $\Delta_{C} \Delta w_{i}=\ln \left(\frac{W_{M i C}}{W_{F i C}}\right)-\ln \left(\frac{W_{M i 0}}{W_{F i 0}}\right)$ for $i=S, U$. We show that the between-industry component of (15) can be simply obtained by multiplying equation (13) by $\sigma$. The withinindustry component can be obtained as the difference between (15) and (33). ${ }^{8}$

\footnotetext{
${ }^{7}$ See Appendix A, Subsection 8.1, for derivation of (11) and its total differential, and derivation of (13) and (14).

${ }^{8}$ See Appendix A, Subsection 8.2, for derivation.
} 


\section{Results}

\subsection{Shift-share analysis of wage bill shares}

In order to assess within- and between-industry components of the observed variation in labor demand, we start by providing a simple shift-share analysis of differences in wage bill shares, as illustrated in equation (7), based on a ten-fold industry classification for each country. ${ }^{9}$ While this classification is arguably rather coarse, a finer one is effectively prevented by both small cell size (by country, gender, skill and industry) and issues of cross-country comparability of more disaggregate industries. The weight of each industry in the total economy for each country is reported in Table A3, together with its demographic composition.

The results are reported in Table 2. Columns 1 and 2 report gender differences in wage bill shares for the unskilled and for the skilled, respectively, and column 3 reports double differences, i.e. the difference between column 1 and column 2. Whereas gender differences in wage bill shares are relatively similar across skill groups in the US, the UK, Denmark and Germany, they are much larger for unskilled than skilled workers in Austria, Ireland and southern Europe, indicating a relatively stronger gender bias in labor demand for the unskilled in the latter group of countries. In column 4 we report triple differences, i.e. crosscountry differences between each country and the US in the unskilled-to-skilled differentials reported in column 4. The interpretation of these figures is that in Canada the unskilled to skilled difference in wage bill gaps is 12.48 percentage points higher than in the US. Except for the UK, such differences are everywhere positive, indicating a relatively stronger gender gap in wage bill shares for the unskilled in all the other countries, relative to the US.

Columns 5 and 6 decompose triple differences in wage bill shares into a between- and a within-industry component, according to expression (7). The between-industry component is typically smaller than the within-industry component. However, there are some noteworthy country differences. The weight of the between-industry components is relatively high in Austria, Finland, Ireland and southern Europe (with the exception of Italy), where the total to be explained is largest (see column 4). Other countries where the between-industry component is also high are the UK and Germany, in which the total is instead negative or positive and small, respectively. In all other countries both the total difference relative to the US and its between-industry component are relatively small.

Finally column 8 reports the proportion of the within-industry component that can be explained by differences in the occupational structure across countries, according to expres-

\footnotetext{
${ }^{9}$ Industry classification is as follows: (1) agriculture, hunting, forestry and fishing; mining and quarrying; electricity, gas and water supply; (2) manufacturing; (3) construction; (4) transport and storage; post and telecommunications; (5) wholesale and retail trade; hotels and restaurants; (6) financial intermediation, insurance and real estate; (7) education; (8) health and social work; (9) other services; (10) public administration and defense.
} 
sion (8). For the sake of cell size, we consider three broad occupation groups, and namely (1) managers, professionals and technical occupations; (2) middle-skill occupations, including clerical and sales occupations, skilled manual and laborer occupations; and (3) service occupations, including all jobs that involve helping, caring for, or assisting others. This is the three-fold occupational classification emphasized by Acemoglu and Autor (2011) in order to illustrate polarization of labor demand. Interestingly, we find that the weight of the between-industry component in the total to be explained (column 7) and the weight of the between-occupation component in the within-industry component (column 8) are positively correlated, and in particular the latter is positive and relatively larger in the UK, Canada, Germany, Belgium, Ireland and southern Europe. In other words, countries where the industry structure favors a certain labor input, relative to the US, tend to have an occupational structure that also tends to favor the same inputs, relative to the US.

Table 3 provides more disaggregate evidence on our shift share analysis, by showing the role of specific industries to the between- and within-industry components of differences in wage bill shares. The upper panel of the table shows that services play the strongest role in driving the between-industry component in most countries. In other words, betweenindustry differences in wage bill shares are mostly driven by international differences in the weight of services, where unskilled women are relatively over-represented. The lower panel in turn shows that all industries of the economy tend to contribute significantly to the withinindustry component of differences in wage bill shares. That is, most industries in the US tend to be relatively more unskilled-women intensive than the corresponding industries in other countries.

As the broad service industry is the one that contributes the most to the between-industry component, in the upper panel of Table 4 we further disaggregate its contribution into six one-digit industries, namely (1) transport and storage; post and telecommunications; (2) wholesale and retail trade; hotels and restaurants; (3) financial intermediation and read estate; (4) education; (5) health and social work; (6) other services. It seems from these figures that the most important one-digit industry for the between-industry component is finance, insurance and real estate, followed by education and transportation. The role of the finance industry mostly stems from its contribution to the difference in the gender gap in labor demand for the skilled between each country and the US. In other words, the finance sector is more intensive in the use of skilled men than skilled women, and given that its weight is larger in the US, this yields a lower gender gap in wage bill shares for the skilled in almost all countries than in the US. This in turn delivers a highly positive unskilled-toskilled difference. A similar argument holds for the education sector, although on a smaller scale. For the transportation industry it is instead its role on the unskilled gender gap in wage bill shares that matters the most, as this industry is relatively smaller in the US, and it employs relatively fewer unskilled women than men. Moving to the within-industry 
component in the lower panel, one can detect an important contribution coming from all 1digit service industries except education and health. This is the case because transportation, trade, finance and other services are all relatively more unskilled-women intensive in the US than elsewhere.

One potential criticism to our analysis is that the simple educational classification used here is based on definitions of qualifications that may not be completely consistent across countries, and also delivers relative group sizes that vary widely across countries. To try to overcome these potential drawbacks, we perform a robustness test based on an alternative skill classification of the population. We first estimate country level wage regressions for males and females separately, including education dummies, age and its square, a marital dummy and year dummies. We then use the resulting wage predictions as continuous human capital indicators. The main difference with respect to the previous classification is that age and marital status are considered as further determinants of an individual's human capital level, and that the predicted human capital level is continuous rather than discrete. We finally construct skill categories by classifying as skilled those with predicted human capital levels in the top tercile of their gender-country specific distribution of predicted wages, and unskilled those in the two bottom terciles. Both raw wage gaps across skills and countries and the results of the shift share decomposition obtained with this alternative definition of skills (here not reported) were very close to those based on educational attainment categories. ${ }^{10}$

\subsection{Historical evidence}

The results of the shift-share analysis above show that over the mid 1990s-early 2000s all countries in our sample, except for the UK, display a relatively stronger gender gap in wage bill shares for the unskilled, relative to the US. We also find that an important portion of this differential is explained by variation in the share of services. This sub-section contains a short digression that investigates how these cross-country differences have evolved over the past four decades.

Micro data that are both harmonized across countries and going far back in time are not easily available. But for the purpose of our analysis it suffices to have information on labor inputs by gender, skill and industry, which we gather using the EU KLEMS database and either censuses or labor force surveys for countries not covered by the EU KLEMS. However, as wage bill shares by gender and skill are not available from the EU KLEMS, the analysis of this section is based on shares in the hours bill. Appendix B gives details of these further

\footnotetext{
${ }^{10} \mathrm{As}$ a further robustness test, we also controlled for occupation (three categories, as described above) in wage regressions, and then again defined as skilled those with predicted wages in the top tercile. We obtained a larger between-industry component of wage bill share differences than that reported in Table 3 , consistent with considerable sorting of occupations across industries so that, say, in countries where services are relatively more important, there is relatively higher demand for service occupations.
} 
data sources and measurement issues.

Table 5 reports gender gaps in hours worked and the corresponding shift share analysis over time. The structure of the Table is the same as in Table 2, except that here we report information for (up to) four points in time for each country.

Columns 1 and 2 report gender differences in hours shares for the unskilled and for the skilled, respectively, and column 3 reports the difference between the two. We first observe that, for both skill groups, the gender gap in hours shares decreases over time in all countries, especially so in the US and Canada. This finding is consistent with results obtained by Heathcote et al. (2010), who show that a large part of the increase in US women's labor force participation over the 1980s and the 1990s can be attributed to a gender biased demand shift. The most noteworthy finding, however, concerns the unskilled-to-skilled differential. In 1971, the gender differential in hours shares in the US is about 26 percentage points higher for the unskilled than for the skilled. By 1991 this double differential drops to approximately 5 percentage points, and stabilizes thereafter, showing convergence over time in skill-specific gender gaps. This tendency can also be detected for all other countries, although the double differential remains substantially higher in 2001 in Europe than in the US. In particular, it could be noted that in Italy, Spain and Greece (as well as the Netherlands) the double differential in 2001 is in the range of $20-25$ percentage points, reaching values that are very similar to that recorded in the US at the start of the sample period. Interestingly, the size of services was growing in all countries during this period, ${ }^{11}$ although its level is at all points in time higher in the US than in southern Europe (see Rogerson, 2008, for a discussion on this point). Thus countries that were lagging behind the US in their process of structural transformation, also had slower convergence in gender gaps in labor demand across skills.

Column 4 reports the usual triple differences, i.e. the difference for each value of column 3 and the corresponding US value, and columns 5 and 6 decompose triple differences in hours shares into between- and within-industry components. Column 7 finally reports the part of the between-industry component that is due to the evolution of services. The betweenindustry component tends to fall over time in most countries, following the expansion of services, but remains relatively high at the end of the sample period in southern Europe.

In summary, we find evidence that the industry structure plays an important role in shaping international differences in skill-specific gender gaps, as well as in their evolution (and convergence) over time. We next assess the role of between- and within-industry forces based on our multi-sector model of labor demand.

\footnotetext{
${ }^{11}$ Within the broad service sector, the industry that has been growing the most in the US is finance, insurance and real estate, consistently with the role of this industry in driving the between-industry component of labor demand across countries, as shown in the previous sub-section.
} 


\subsection{A model-based decomposition of the gender bias in labor de- mand}

We have shown in Section 5 that the components of the shift-share analysis can be used to assess the extent to which the variation in the male bias in labor demand may be driven by cross-country differences in labor input intensities within industries $\left(\beta_{i j}\right)$, or differences in product demand across industries with different input intensities $\left(\theta_{j}\right)$.

The results of this decomposition are reported in Table 6. Column 1 reports the triple difference in log wage bill shares, described in expression (12). Column 2 reports its between industry component (obtained using expression (13)), and column 3 reports its weight on the total difference. This decomposition corresponds to the Cobb-Douglas case, and is conceptually similar to the simple share analysis reported in Table 2, with the noteworthy difference that here we are decomposing log, as oppose to absolute, wage bill differences, as implied by the CES model for labor demand. The results are qualitatively similar to those reported in Table 2. The notable exception is that, comparing column 4 in Table 2 to column 1 in Table 6, the sign of the triple difference in wage bill shares switches from positive to negative for Germany and the Netherlands, as we move from absolute to log differences. However, the sign of the between-industry component in column 2 of Table 6 is unchanged from Table 2 for all countries, and its relative weight in the triple difference in labor demand tends to be higher than in the shift-share analysis.

The rest of the Table reports decomposition results for the case in which $S_{j}$ and $U_{j}$ are CES aggregators of male and female labor inputs, with $\sigma=2.5$. This extension is important as the few empirical studies in this area have consistently found values of the male-female elasticity of substitution greater than 1. Hamermesh (1993) reviews two such studies that report values of the male-female elasticity of substitution of 2 and 2.3 for the UK and Australia, respectively (Layard, 1983; Lewis, 1985). More recently, Weinberg (2000) obtains an estimate for this parameter for the US of 2.4, which is remarkably similar to the values obtained for Australia and the UK, and Acemoglu, Autor and Lyle (2004) obtain a slightly higher estimate of about 3. Given this range of estimates, we choose to report results based on $\sigma=2.5$, which roughly coincides with the mean of existing estimates.

As equation (33) implies, the between-industry component varies proportionally with $\sigma$, which is what we empirically observe comparing columns 2 and 5 of Table 6 . This is not the case for the within-industry component. ${ }^{12}$ Thus the total difference to be explained varies less than proportionally with $\sigma$. It follows that the relative importance of the betweenindustry component in the total variation in labor demand increases with $\sigma$. In particular, adopting a value for $\sigma$ of 2.5, we find that the between-industry component explains about

\footnotetext{
${ }^{12}$ This can be seen from equation (29) in Appendix A, where the between-industry component term $\theta_{j}$ is raised to the power $\sigma$, but the within-industry component $B_{M h j}$ is raised to the power $1-\sigma$.
} 
half or more of the variation in labor demand everywhere except Canada, Germany, Belgium and Spain.

A very stylized way to provide a quantitative assessment of the importance of the betweenindustry component of labor demand for the observed variation in gender gaps consists in going back to our simple correlation analysis of Figure 1, and asking what sort of correlation between the unskilled-to-skilled wage gap and the corresponding hours gap one would observe, having corrected wage gaps for the between-industry component of labor demand obtained in Table 6 .

For example, using equation (6), the corrected triple difference in log wages in the CobbDouglas case would be

$$
\Delta_{C}\left(\Delta w_{U}-\Delta w_{S}\right)-\Delta_{C}\left(\widetilde{\beta}_{U}^{\text {between }}-\widetilde{\beta}_{S}^{\text {between }}\right),
$$

where $\Delta_{C} \widetilde{\beta}_{i}^{\text {between }}$ is given by equation (13). Note that, for the CES case, the corrected triple difference remains the same as in equation (16), given equations (6) and (33). This implies that the wage gap adjusted for the between-industry component of labor demand is independent of the elasticity of substitution between male and female labor inputs.

Figure 5 plots the unskilled-to-skilled difference in the adjusted wage gap according to (16), versus the unskilled-to-skilled difference in the hours gap. Once the between-industry component of labor demand is removed from relative wages, the correlation between wage and hours gaps falls to 0.14 , and it is not significantly different from zero. In other words, the between-industry component of differences in labor demand can explain two thirds of the observed correlation between wage and hours gaps across skills and countries.

While we have no direct evidence on the forces driving differences in the industry structure across countries, an explanation that has often been put forward is based on differences in the rate of marketization of activities that can be both performed in the market or within the household, like childcare, elderly care, cooking, house repairs, gardening etc. If outsourced to the market, all these activities would be part of the broad service sector. Freeman and Schettkat (2005) provide rich evidence on the marketization hypothesis, based on both time-use data and expenditure data across countries, and conclude that this hypothesis contributes substantially to the hours gap across the Atlantic. In a similar vein, Rogerson (2008) relates the relative poor performance of continental EU labor markets to a relatively under-marketized service industry. Marketization of services can in turn be hindered in continental Europe by higher tax rates, which distort market-home substitution, and the slow down in productivity growth. Ngai and Pissarides (2011) provide evidence on this mechanism for a number of OECD countries by showing that taxation and subsidies decrease and raise hours, respectively, in sectors that have close home substitutes.

Using a tenfold industry classification, Table 4 above has shown that the between-industry component of differences in labor demand between each country and the US is positive for 
most service industries, which arguably include activities that can otherwise be performed in the household, like childcare (included in education), elderly care (included in health), and various personal services (included in other services). Thus under-marketization of these activities in Europe is consistent with our results, but the marketization hypothesis does not seem to be the only or main story shaping international differences in labor demand, because we noted in Table 4 the substantial contribution of the finance industry to the between-industry component of differences in labor demand, and arguably there is not much substitution between market and household provision within this industry. There are thus important differences in the industry composition of consumer's demand, that cannot be explained by substitution between market and home production.

\section{Conclusions}

This paper uncovers a strong, positive correlation between the unskilled-to-skilled wage gap and the corresponding hours gap across countries, thus pointing at significant (net) demand forces shaping gender differences in labor market outcomes across skills. Of course, when cross-country differences are considered, one should also allow for the role of institutions and/or social norms, that would differently affect the labor supply prospects of various skill groups in different countries, but we provide some evidence that neither of them seem to wash away or even dampen the observed correlation between wage and hours gaps.

Our findings point to a lack of demand as the main cause for the dismal labor market outcomes of less-skilled women in some of the countries in our sample. Moreover, when we decompose such demand differences into a between- and within-industry component, we find that both play important roles. The within-industry component is explained by the fact that most sectors in the US tend to be more unskilled-women intensive than in the majority of other countries. The between-industry component is instead explained by the larger share of services in the US, as the relative demand for unskilled women is higher in services than in other sectors of the economy. In particular, for realistic values of the elasticity of substitution between male and female labor inputs, the between-industry component explains about half or more of the variation in labor demand in all countries in the sample except Canada, Germany, Belgium and Spain. Adjusting unskilled-to-skilled wage gaps across countries for the between-industry component of labor demand reduces the corresponding correlation with hours gaps from 0.41 to 0.14 . 


\section{Appendix A: Details on the multisector model of la- bor demand}

\subsection{The Cobb-Douglas case}

In a multisector model, equations (2) and (3) can be re-written as

$$
S_{j}=\left[\beta_{S j}\left(B_{M S j} M_{S j}\right)^{\rho_{S}}+\left(1-\beta_{S j}\right)\left(B_{F S j} F_{S j}\right)^{\rho_{S}}\right]^{1 / \rho_{S}}
$$

and

$$
U_{j}=\left[\beta_{U j}\left(B_{M U j} M_{U j}\right)^{\rho_{U}}+\left(1-\beta_{U j}\right)\left(B_{F U j} F_{U j}\right)^{\rho_{U}}\right]^{1 / \rho_{U}},
$$

where the technology parameters $\beta_{i j}, B_{M i j}$ and $B_{F i j}, i=S, U$, are industry-specific, while the elasticities of substitution $\sigma_{i}=1 /\left(1-\rho_{i}\right)$ are kept constant.

Under perfect competition in the labor market, all inputs are paid their marginal productivity, thus male wages for skill group $i$ in industry $j$ are given by:

$$
W_{M i j}=P_{j} \frac{\partial Q_{j}}{\partial M_{i j}}=\theta_{j} Q_{j}^{1 / \sigma-1} \alpha M_{i j}^{1 / \sigma_{i}-1 / \sigma} \beta_{i j} B_{M i j}^{1-1 / \sigma_{i}} M_{i j}^{-1 / \sigma_{i}}
$$

after normalizing $Q_{R}=1$.

We assume further a Cobb-Douglas economy with $\bar{\sigma}=\sigma_{S}=\sigma_{U}=1$, which implies

$$
W_{M i}=\frac{\alpha \theta_{j} \beta_{i j}}{M_{i j}}
$$

after imposing $W_{M i j}=W_{M i}$ due to perfect mobility of labor across industries.

Summing up across industries implies $W_{M i} \sum_{j} M_{i j}=\alpha \sum_{j} \theta_{j} \beta_{i j}$, which can be solved for $W_{M i}$ :

$$
W_{M i}=\frac{\alpha \sum_{j} \theta_{j} \beta_{i j}}{M_{i}} .
$$

Combining (21) with a similar expression for female wages delivers the following gender wage gap for skill group $i$ :

$$
\Delta w_{i}=\widetilde{\beta}_{i}-\Delta h_{i}
$$

with

$$
\widetilde{\beta}_{i}=\ln \left(\frac{\sum_{j} \beta_{i j} \theta_{j}}{\sum_{j}\left(1-\beta_{i j}\right) \theta_{j}}\right),
$$

which coincides with expression (11) in the text.

We next evaluate the total cross-country differential of expression (23):

$$
\Delta_{C} \widetilde{\beta}_{i}=\frac{\sum_{j} \beta_{i j C} \Delta_{C} \theta_{j}+\sum_{j} \theta_{j C} \Delta_{C} \beta_{i j}}{y_{M i C}}-\frac{\sum_{j}\left(1-\beta_{i j C}\right) \Delta_{C} \theta_{j}+\sum_{j} \theta_{j C} \Delta_{C} \beta_{i j}}{y_{F i C}}
$$


where $y_{M i C}=\sum_{j} \beta_{i j C} \theta_{j C}$ and $y_{F i C}=\sum_{j}\left(1-\beta_{i j C}\right) \theta_{j C}$.

Rearranging, we obtain $\Delta_{C} \widetilde{\beta}_{i}=\Delta_{C} \widetilde{\beta}_{i}^{\text {between }}+\Delta_{C} \widetilde{\beta}_{i}^{\text {within }}$, where:

$$
\begin{aligned}
\Delta_{C} \widetilde{\beta}_{i}^{\text {between }} & =\frac{\sum_{j} \beta_{i j C} \Delta_{C} \theta_{j}}{y_{M i C}}-\frac{\sum_{j}\left(1-\beta_{i j C}\right) \Delta_{C} \theta_{j}}{y_{F i C}} \\
& =\frac{\sum_{j} \frac{Y_{M i j C}}{Y_{j C}}\left(\frac{Y_{j C}}{Y_{C}}-\frac{Y_{j 0}}{Y_{0}}\right)}{y_{M i C}}-\frac{\sum_{j} \frac{Y_{F i j C}}{Y_{j C}}\left(\frac{Y_{j C}}{Y_{C}}-\frac{Y_{j 0}}{Y_{0}}\right)}{y_{F i C}}
\end{aligned}
$$

and

$$
\begin{aligned}
\Delta_{C} \widetilde{\beta}_{i}^{\text {within }} & =\frac{\sum_{j} \theta_{j C} \Delta_{C} \beta_{i j}}{y_{M i C}}-\frac{\sum_{j} \theta_{j C} \Delta_{C} \beta_{i j}}{y_{F i C}} \\
& =\frac{\sum_{j} \frac{Y_{j C}}{Y_{c}}\left(\frac{Y_{M i j C}}{Y_{j C}}-\frac{Y_{M i j 0}}{Y_{j 0}}\right)}{y_{M i C}}-\frac{\sum_{j} \frac{Y_{j C}}{Y_{c}}\left(\frac{Y_{F i j C}}{Y_{j C}}-\frac{Y_{F i j 0}}{Y_{j 0}}\right)}{y_{F i C}}
\end{aligned}
$$

represents the between- and within-industry components, respectively.

For ease of exposition we have expressed the whole decomposition above in terms of infinitesimal changes in relevant variables. When applied to cross-country differences, these are approximated with the finite-change equivalent in equations (25) and (26). These two components sum up exactly to the total (24) only for infinitesimal changes in relevant magnitudes, while this decomposition is approximate for finite changes. However, we noted in our data that the approximation involved was typically very small.

\subsection{The more general CES case}

Under the CES assumptions, equation (19) implies

$$
W_{M i}=\left(\frac{\alpha^{\sigma} \sum_{j} \theta_{j}^{\sigma} \beta_{i j}^{\sigma} B_{M i j}^{\sigma-1} M_{i j}^{1-\sigma}}{M_{i}}\right)^{1 / \sigma}
$$

and the log gender wage gap for group $i$ is equal to

$$
\Delta w_{i}=\frac{1}{\sigma}\left(\widetilde{\beta}_{i}-\Delta h_{i}\right)
$$

where:

$$
\widetilde{\beta}_{i}=\ln \left(\frac{\sum_{j} \theta_{j}^{\sigma} \beta_{i j}^{\sigma} B_{M i j}^{\sigma-1} M_{i j}^{1-\sigma}}{\sum_{j} \theta_{j}^{\sigma}\left(1-\beta_{i j}\right)^{\sigma} B_{F i j}^{\sigma-1} F_{i j}^{1-\sigma}}\right) .
$$

One can next differentiate $\widetilde{\beta}_{i}$ with respect to $\theta_{j}$ to obtain the between-industry component of cross-country differences in $\widetilde{\beta}_{i}$ :

$$
\Delta_{C} \widetilde{\beta}_{i}^{\text {between }}=\frac{\sigma \sum_{j} \beta_{i j C}^{\sigma} B_{M i j C}^{\sigma-1} M_{i j C}^{1-\sigma} \theta_{j C}^{\sigma-1} \Delta_{C} \theta_{j}}{\sum_{j} \beta_{i j C}^{\sigma} B_{M i j C}^{\sigma-1} M_{i j C}^{1-\sigma} \theta_{j C}^{\sigma}}-\frac{\sigma \sum_{j}\left(1-\beta_{i j C}\right)^{\sigma} B_{F i j C}^{\sigma-1} F_{i j C}^{1-\sigma} \theta_{j C}^{\sigma-1} \Delta_{C} \theta_{j}}{\sum_{j}\left(1-\beta_{i j C}\right)^{\sigma} B_{F i j C}^{\sigma-1} F_{i j C}^{1-\sigma} \theta_{j C}^{\sigma}} .
$$


Using the first order condition for wages (i.e. (19) for male wages and the corresponding one for female wages), the $\beta_{i j C}^{\sigma}$ and $\left(1-\beta_{i j C}\right)^{\sigma}$ terms can be solved for as

$$
\begin{aligned}
\beta_{i j}^{\sigma} & =\frac{w_{M i}^{\sigma} M_{i j}}{\alpha^{\sigma} \theta_{j}^{\sigma} B_{M i j}^{\sigma-1} M_{i j}^{1-\sigma}} \\
\left(1-\beta_{i j}\right)^{\sigma} & =\frac{w_{F i}^{\sigma} F_{i j}}{\alpha^{\sigma} \theta_{j}^{\sigma} B_{F i j}^{\sigma-1} F_{i j}^{1-\sigma}} .
\end{aligned}
$$

Substituting (31) and (32) into (30) gives

$$
\Delta_{C} \widetilde{\beta}_{i}^{\text {between }}=\sigma \frac{\sum_{j} w_{M i C} M_{i j C} \theta_{j C}^{-1} \Delta_{C} \theta_{j}}{w_{M i C} M_{i C}}-\sigma \frac{\sum_{j} w_{F i C} F_{i j C} \theta_{j C}^{-1} \Delta_{C} \theta_{j}}{w_{F i C} F_{i C}} .
$$

Finally, using $\theta_{j C}=Y_{j C} / Y_{C}$ and finite-change approximations yields

$$
\Delta_{C} \widetilde{\beta}_{i C}^{\text {between }}=\sigma\left(\frac{\sum_{j} \frac{Y_{M i j C}}{Y_{j C}}\left(\frac{Y_{j C}}{Y_{C}}-\frac{Y_{j 0}}{Y_{0}}\right)}{y_{M i C}}+\frac{\sum_{j} \frac{Y_{F i j C}}{Y_{j C}}\left(\frac{Y_{j C}}{Y_{C}}-\frac{Y_{j 0}}{Y_{0}}\right)}{y_{F i C}}\right)
$$

\section{Appendix B: EU-Klems data}

Time series evidence on the evolution of labor demand for various labor inputs in the countries considered can be obtained using data from the EU KLEMS Growth and Productivity Accounts. This database includes industry-level measures of output and input growth, and derived variables such as multi-factor productivity, for several European countries, Canada, Australia, Japan and the US. Its coverage starts in 1970 and is annual thereafter. ${ }^{13}$ Although these data have been constructed by using growth accounting as an organizing principle, they can be used for our application since they derive industry-level measures of labor inputs for 18 demographic groups defined by gender, skill (low, medium and high) and age (15 to 29, 30 to 49 and 50 plus). Unfortunately disaggregated labor input data are not available for some of the countries in our sample, and namely France, Greece, Ireland, and Portugal. Thus we augment the EU KLEMS sample using a variety of data sources. For Greece and Portugal we use IPUMS-International public-use Census data available for 1971-2001 and 1991-2001, respectively. For France we use data from the Enquete Emploi for the period 1981-2001. Unfortunately, we could not obtain publicly available data for Ireland so this country is not included in the time series analysis. Using these different data sources we build an unbalanced panel of 14 countries, containing harmonized industry-level measures of labor inputs of interest. Specifically, we show evidence for four data points, 1971, 1981, 1991 and 2001, or as subset of these years when not all data points are available for some country.

\footnotetext{
${ }^{13}$ The database is publicly available at http://www.euklems.net. See O’Mahony and Timmer (2009) for a description of the methodology employed in constructing the database.
} 
For all the countries in our sample we construct crosswalks by industry in order to replicate the tenfold industry classification as in our main cross-section analysis (crosswalks available upon request). In order to define skill groups consistently with the rest of our analysis, we define as skilled those in the high-skill group in the EU KLEMS, corresponding to college graduates, and as unskilled all the others (see Timmer et. al, 2007, for a detailed description of measurement issues in EU KLEMS). Similarly, for France, Greece and Portugal, we define as skilled those with college education.

While our main shift share analysis is based on wage bill shares, historical evidence that we obtain from the EU KLEMS is based on hours shares. This is because, as discussed in O'Mahony and Timmer (2009), imputation of missing wage information by demographic group in the EU KLEMS makes gender comparisons of wage bill shares unfeasible for some of the countries covered. Moreover, the IPUMS-International data available for Greece and Portugal do not include information on earnings. 


\section{References}

[1] Acemoglu, Daron and David H. Autor. 2011. Skills, Tasks and Technologies: Implications for Employment and Earnings, in Orley Ashenfelter and David Card, eds., Handbook of Labor Economics, Vol. 4B, Amsterdam: Elsevier-NorthHolland, pp. 1043-1171.

[2] Acemoglu, Daron, Autor, David H. and David Lyle. 2004. Women, War, and Wages: The Effect of Female Labor Supply on the Wage Structure at Mid-century. Journal of Political Economy, 112 (3), 497-551.

[3] Autor, David H., Katz, Lawrence F. and Alan B. Krueger. 1998. Computing Inequality: Have Computers Changed The Labor Market? Quarterly Journal of Economics, 113 (4): 1169-1213.

[4] Autor, David H., Levy, Frank and Richard J. Murnane. 2003. The Skill Content of Recent Technological Change: An Empirical Investigation. Quarterly Journal of Economics 118 (4): 1279-1333.

[5] Autor, David H. and David Dorn. 2010. Inequality and Specialization: The Growth of Low-Skill Service Jobs in the United States. NBER Working Paper No. 15150.

[6] Black, Sandra E., and Alexandra Spitz-Oener. 2009. Explaining Women's Success: Technological Change and the Skill Content of Women's Work. Review of Economics and Statistics, 92 (1), 187-194.

[7] Blau, Francine D., and Lawrence M. Kahn. 1996. Wage Structure and Gender Earnings Differentials: An International Comparison. Economica 63: 29-62.

[8] Blau, Francine D., and Lawrence M. Kahn. 2003. Understanding International Differences in the Gender Pay Gap. Journal of Labor Economics 21: 106-144.

[9] Blau, Francine D., and Lawrence M. Kahn. 2006. The US Gender Pay Gap in the 1990s: Slowing Convergence? Industrial and Labor Relations Review 60: 45-66.

[10] Bound, John, and George Johnson. 1992. Changes in the Structure of Wages in the 1980s: An Evaluation of Alternative Explanations. American Economic Review, LXXXII: $371-392$.

[11] Fortin, Nicole M. 2005. Gender Role Attitudes and the Labour Market Outcomes of Women Across OECD Countries. Oxford Review of Economic Policy, 21: 416-438.

[12] Freeman, Richard B. and Ronald Schettkat. 2005. Marketization of Household Production and the EU-US Gap in Work. Economic Policy 20: 6-50. 
[13] Goos, Maarten, and Alan Manning. 2007. Lousy and Lovely Jobs: The Rising Polarization of Work in Britain. Review of Economics and Statistics 89 (1): 118-33.

[14] Goos, Maarten, Manning, Alan and Anna Salomons. 2010. Explaining Job Polarization in Europe: The Roles of Technology, Globalization and Institutions. CEP Discussion Paper No. 1026.

[15] Hamermesh, Daniel S. 1993. Labor Demand Princeton, NJ: Princeton University Press.

[16] Heathcote, Jonathan, Kjetil Storesletten and Gianluca Violante. 2010. The Macroeconomic Implications of Rising Wage Inequality in the United States. Journal of Political Economy 118 (4): 681-722.

[17] Katz Lawrence F. and Kevin M. Murphy. 1992. Changes in Relative Wages, 1963-1987: Supply and Demand Factors. Quarterly Journal of Economics, 107 (1): 35-78.

[18] Katz, Lawrence F. and David H. Autor. 1999. Changes in the Wage Structure and Earnings Inequality, in Orley Ashenfelter and David Card, eds., Handbook of Labor Economics, vol. 3A, Amsterdam: Elsevier Science, pp. 1463-1555.

[19] Layard, Richard. 1982. Youth Unemployment in Britain and the United States Compared, in Richard B. Freeman and David A. Wise, eds., The Youth Labor Market Problem: Its Nature, Causes, and Consequences, Chicago: University of Chicago Press, pp. 499-542.

[20] Lewis, Philip E. T. 1985. Substitution Between Young and Adult Workers in Australia. Australian Economic Papers 24: 115-126.

[21] Mulligan, Casey B., and Yona Rubinstein. 2008. Selection, Investment, and Women's Relative Wages Over Time. Quarterly Journal of Economics 123 (3): 1061-1110.

[22] Nickell, W. 2006. The CEP-OECD Institutions Data Set. CEP Discussion Paper No. 759 .

[23] Ngai, L. Rachel and Christopher A. Pissarides. 2008. Trends in Hours and Economic Growth. Review of Economic Dynamics 11 (2): 239-256.

[24] Ngai, L. Rachel and Christopher A. Pissarides. 2011. Taxes, Social Subsidies and the Allocation of Work Time. American Economic Journal - Macroeconomics, forthcoming.

[25] Olivetti, Claudia, and Barbara Petrongolo. 2008. Unequal Pay or Unequal Employment? A Cross-Country Analysis of Gender Gaps. Journal of Labor Economics 26: 621-654. 
[26] O'Mahony, Mary and Marcel P. Timmer. 2009. Output, Input and Productivity Measures at the Industry Level: The EU KLEMS Database. The Economic Journal 119: F374-F403.

[27] Rogerson, Richard. 2008. Structural Transformation and the Deterioration of European Labor Markets. Journal of Political Economy 166: 235-258.

[28] Timmer, Marcel P., O’Mahony, Mary and Bart van Ark. 2007. The EU KLEMS Growth and Productivity Accounts: An Overview. Available at textit www.euklems.net

[29] United Nations. 2009. UN Millennium Development Goals Report. New York: United Nations.

[30] Weinberg, Bruce A. 2000. Computer Use and the Demand for Female Workers. Industrial and Labor Relations Review 53: 290-308. 
Figure 1

Gender gaps in (log) hourly wages by educational attainment

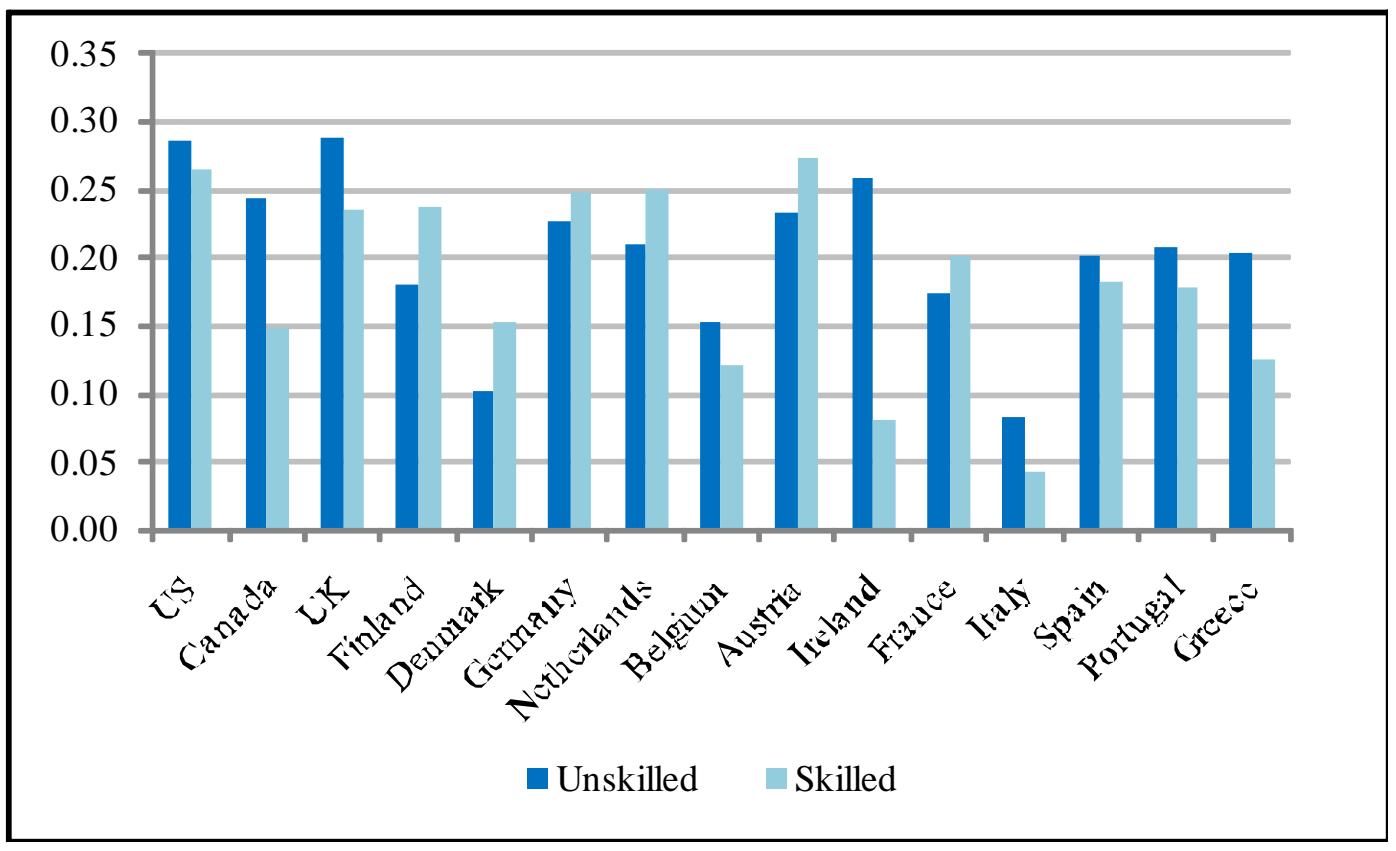

Notes. The skilled are those with a college degree; the unskilled are all others. Values displayed are coefficients on a male dummy from log wage regressions by country and education, which control for gender and year effects, using population weights. All estimates are significant at the $1 \%$ level. Sample: men and women aged 25-54, excluding military, students, and self employed. Sample period: 1994-2001, except for Canada (1997-2004), Finland (1996-2001) and Austria (1995-2001). Source: CPS, Canadian LFS, and ECHPS.

Figure 2

Gender gaps in (log) weekly hours by educational attainment

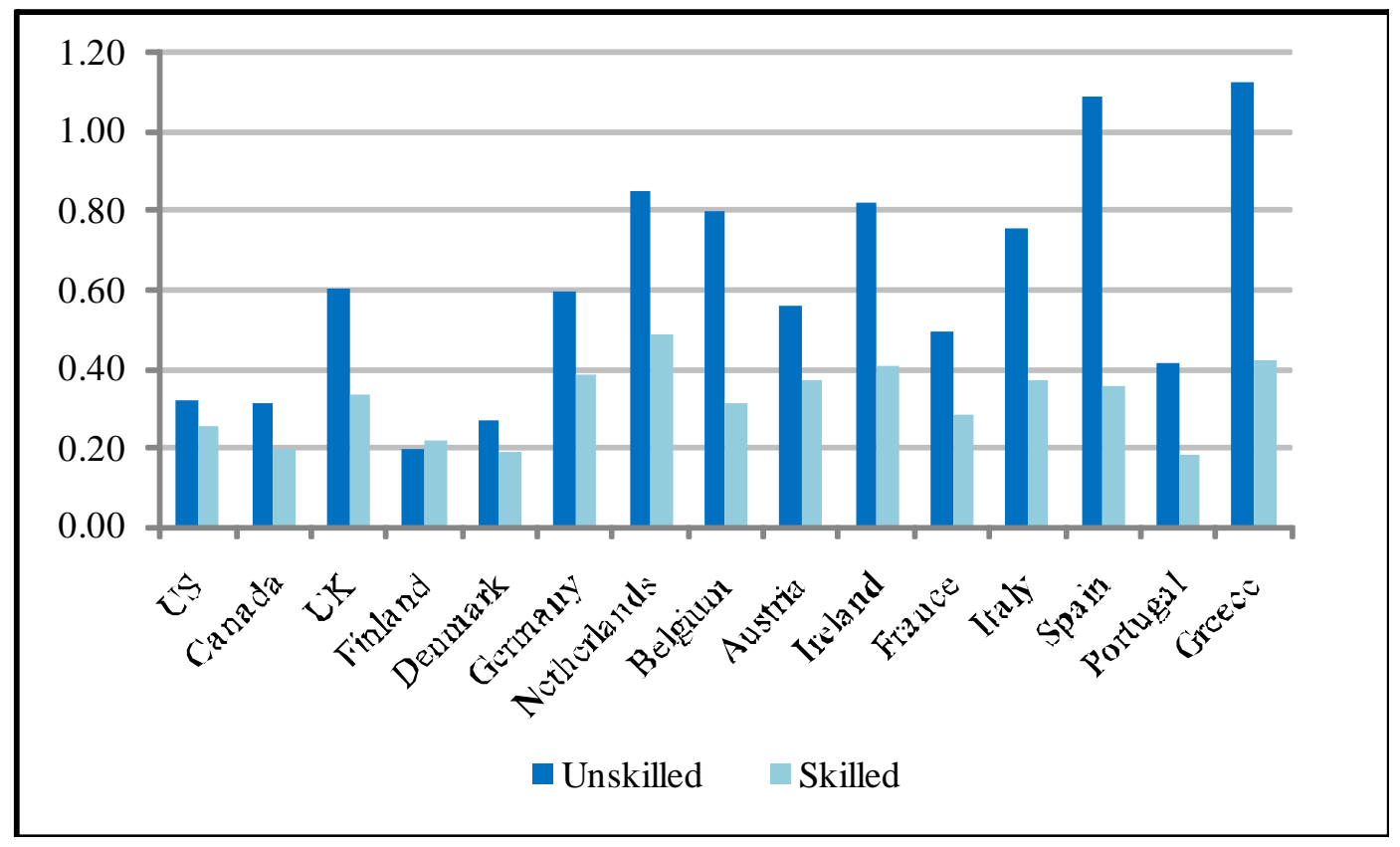

Notes. Values displayed are gender differences in $\log$ (hours/population) by country and skill, using population weights. See notes to Figure 1 for samples and source. 
Figure 3

Unskilled-to-skilled difference in gender gaps across countries.

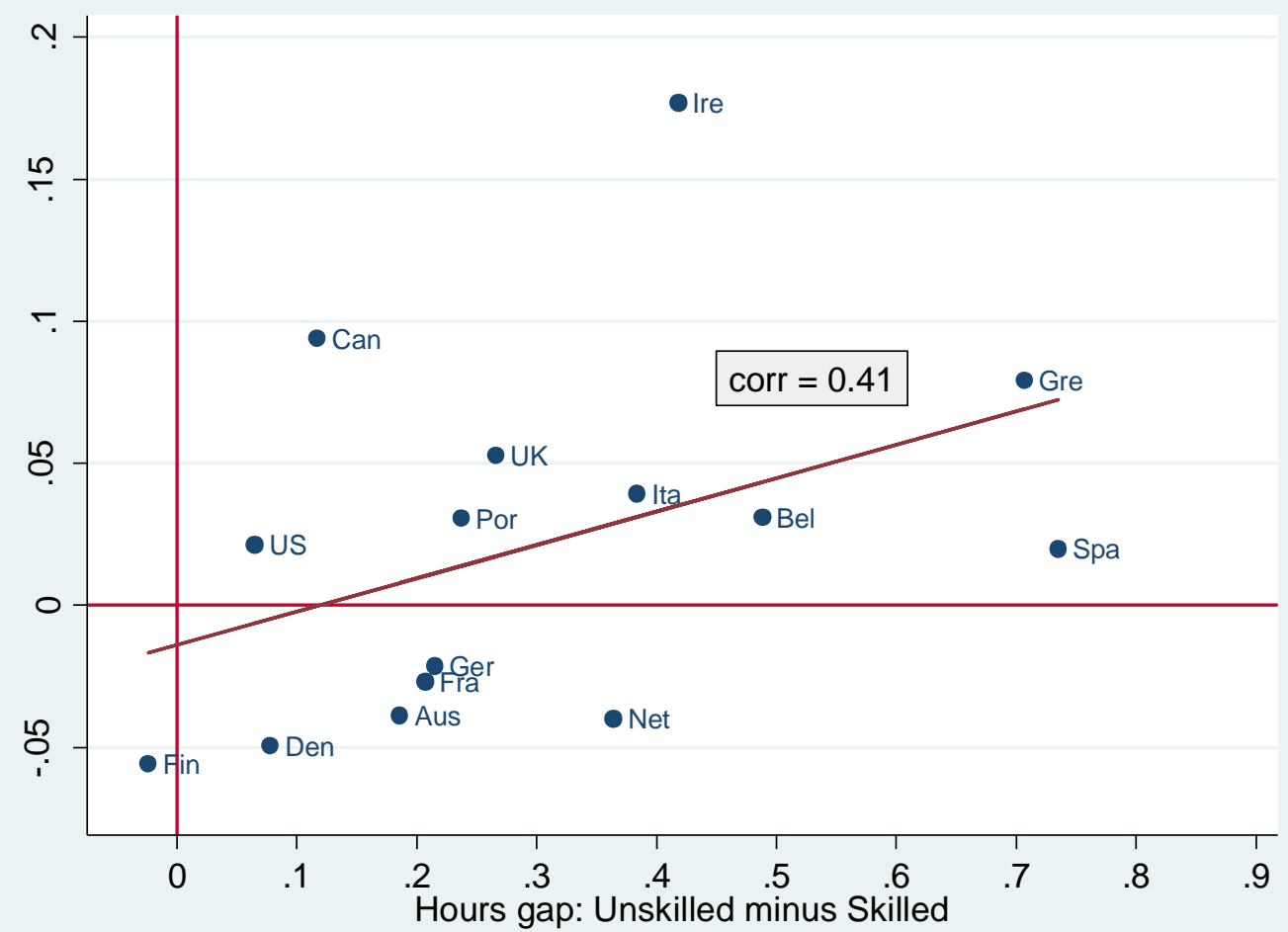

Notes. Wage and hours gap are defined in notes to Figures 1 and 2, respectively. 
Figure 4

Unskilled-to-skilled difference in gender gaps across countries: The role of selection

Panel A: Wage gaps corrected for selection based on unemployed versus nonparticipant status

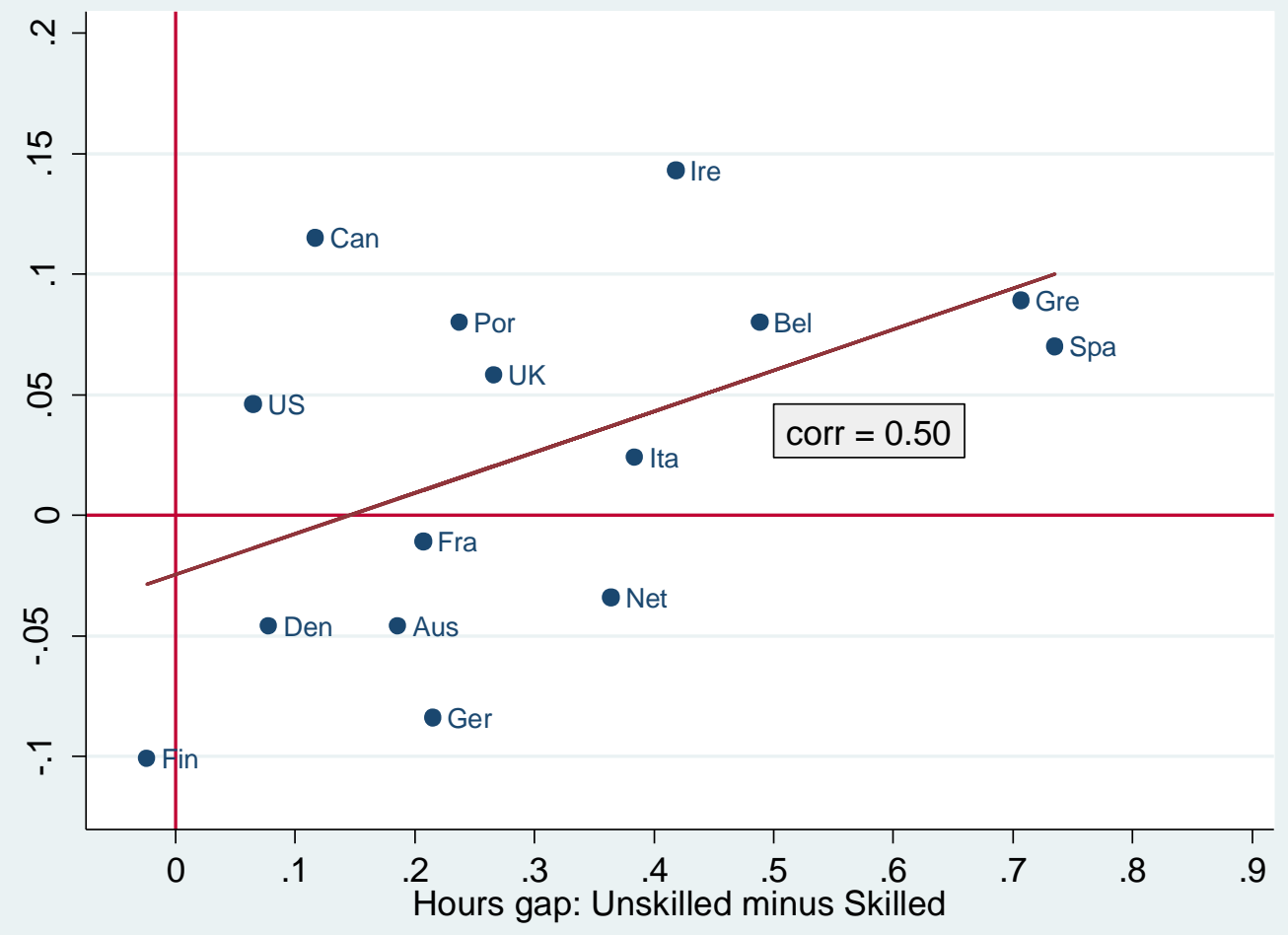

Panel B: Wage gaps corrected for selection based on quartile of spouse income

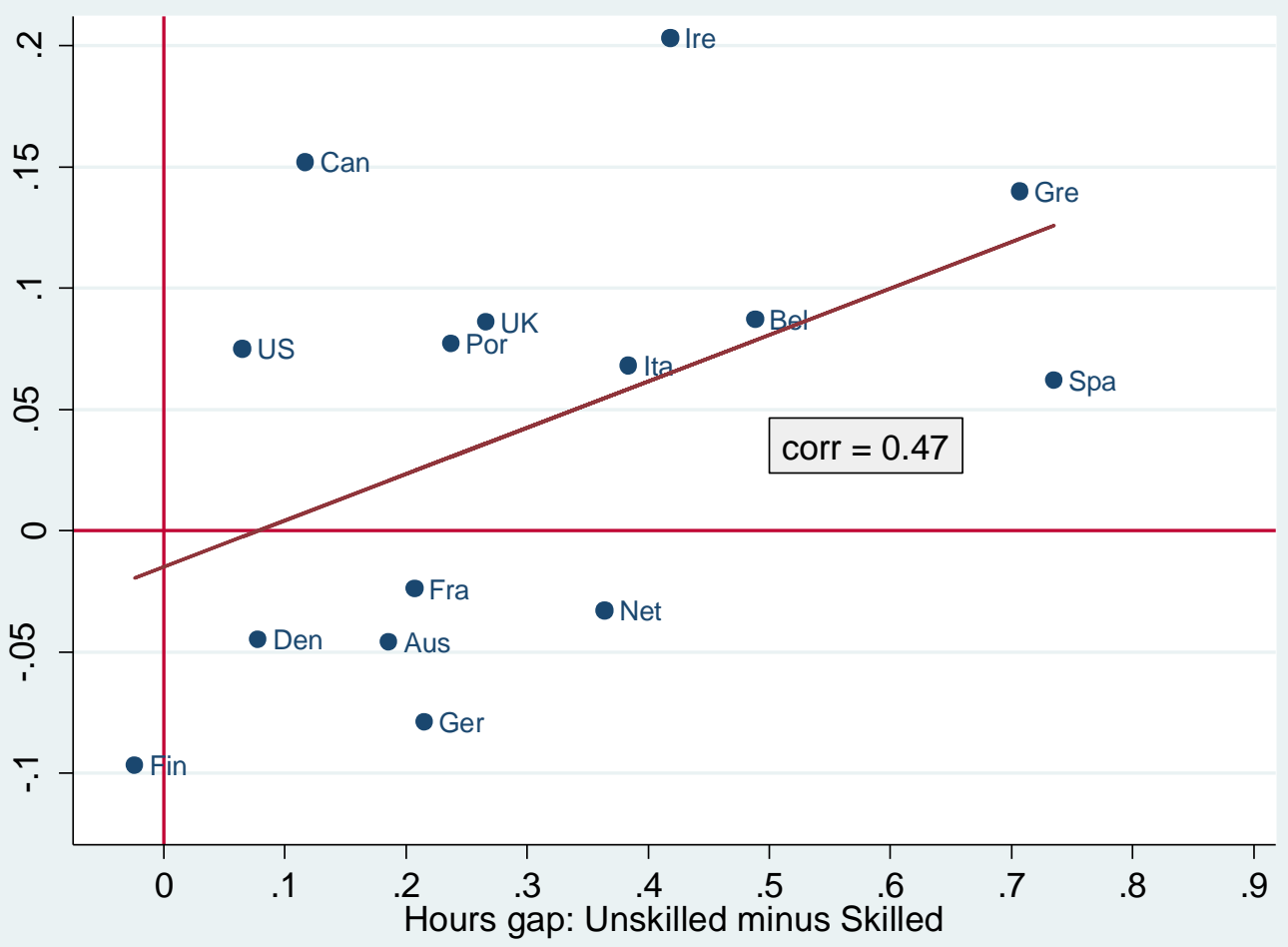

Notes. Selection corrected wage gaps are described on pages 10 and 11 in the text. Hours gap are defined in notes to Figure 2. See notes to Figure 1 for samples and sources. 
Figure 5

Unskilled-to-skilled difference in gender gaps across countries.

Wage gaps adjusted for the between-industry component of differences in labor demand.

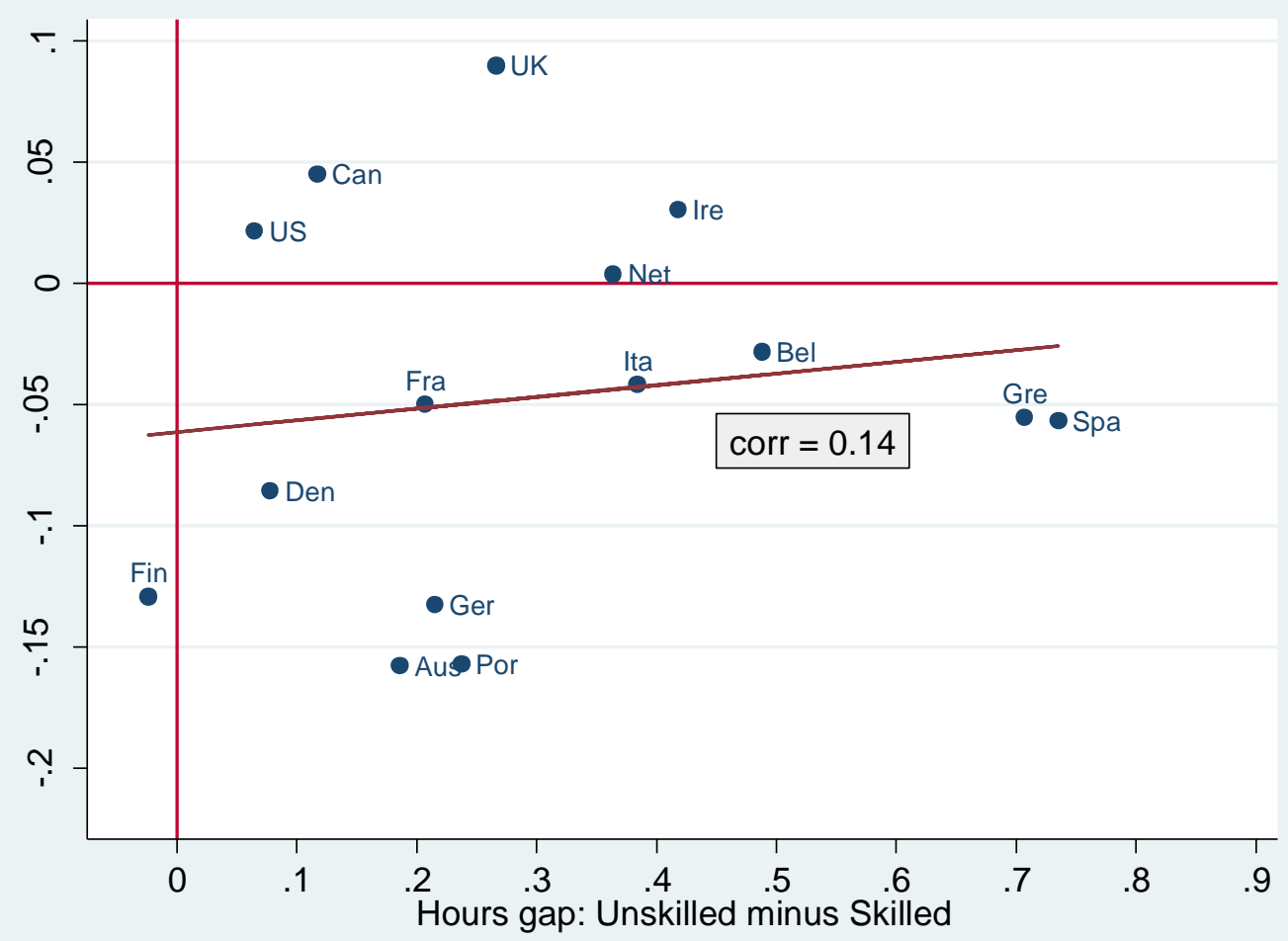

Notes. Adjusted wage gaps are obtained from equation (16) in the text. Notes. Hours gap are defined in notes to Figure 2. See notes to Figure 1 for samples and sources. 
Table 1

Unskilled-to-skilled difference in gender gaps across countries: Partial correlations.

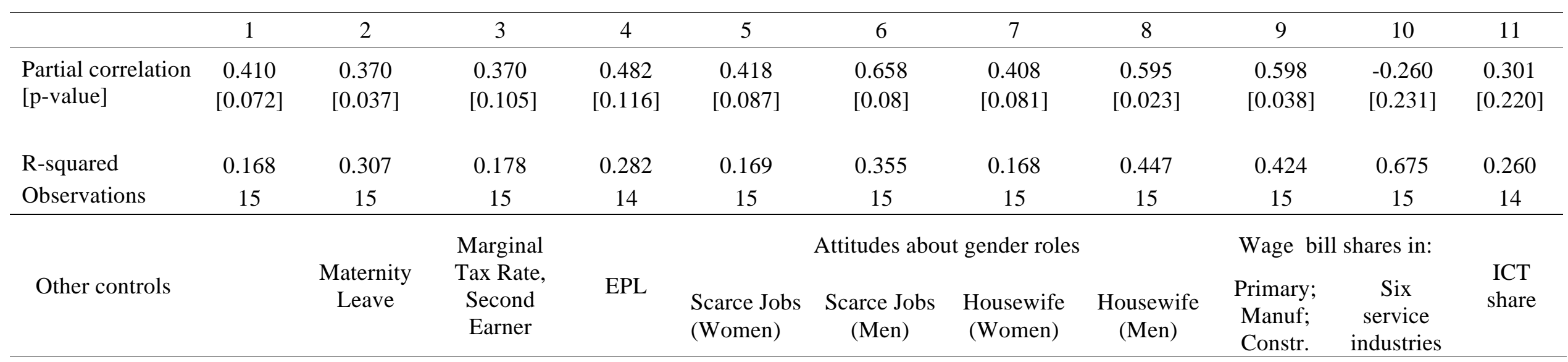

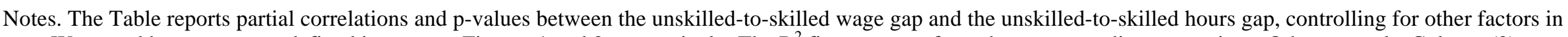
turn. Wage and hours gaps are defined in notes to Figures 1 and 2, respectively. The $\mathrm{R}^{2}$ figures come from the corresponding regressions. Other controls. Column (2):

Maximum length of maternity leave in weeks. Source: OECD Family Database, Table PF2.1.A, available at:

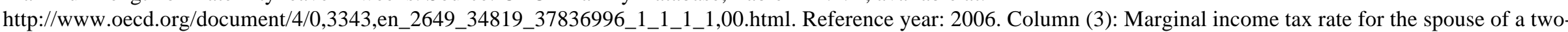

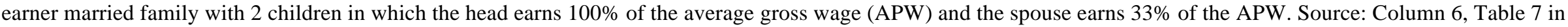

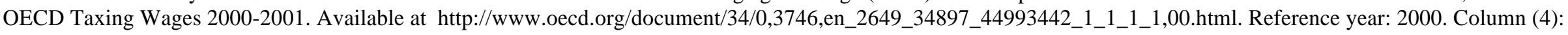

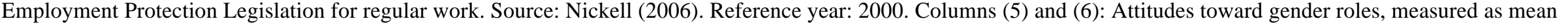

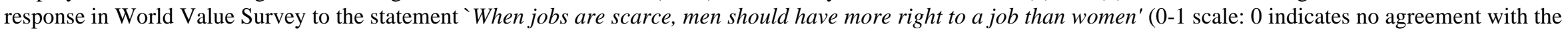

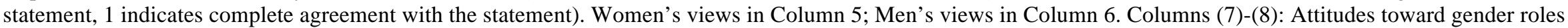

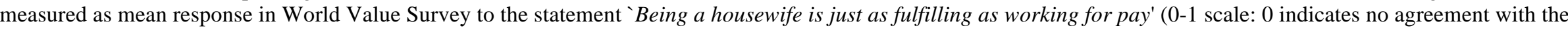

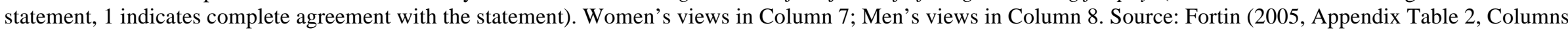

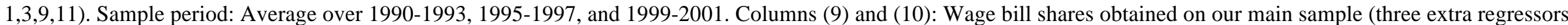
in Column 9, six extra regressors in column 10, referring to transport, storage and post and telecommunications; wholesale and retail trade and hotels and restaurants;

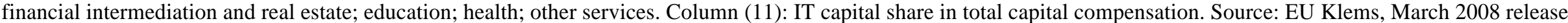
(available at http://www.euklems.net/). In columns (4) and (11) data for Greece are not available. 
Table 2

Shift share decomposition of differences in wage bill shares $(\mathbf{x 1 0 0})$

\begin{tabular}{|c|c|c|c|c|c|c|c|c|}
\hline \multirow[b]{3}{*}{ Countries } & 1 & 2 & 3 & 4 & 5 & 6 & 7 & 8 \\
\hline & $\begin{array}{r}\text { Genc } \\
\text { in wage }\end{array}$ & $\begin{array}{l}\text { yaps } \\
\text { shares }\end{array}$ & \multirow{2}{*}{$\begin{array}{l}\text { Difference } \\
\text { (1)-(2) }\end{array}$} & \multirow{2}{*}{$\begin{array}{l}\text { Cross- } \\
\text { country } \\
\text { difference }\end{array}$} & \multirow{2}{*}{$\begin{array}{l}\text { Between } \\
\text { industry } \\
\text { component }\end{array}$} & \multirow{2}{*}{$\begin{array}{c}\text { Within } \\
\text { industry } \\
\text { component }\end{array}$} & \multirow{2}{*}{$\begin{array}{c}\% \text { between } \\
\text { industry } \\
100 *(5) /(4)\end{array}$} & \multirow{2}{*}{$\begin{array}{c}\% \text { of } \\
\text { within } \\
\text { industry } \\
\text { componen } \\
\text { that is } \\
\text { between } \\
\text { occupation }\end{array}$} \\
\hline & Unskilled & Skilled & & & & & & \\
\hline US & 11.29 & 10.36 & 0.93 & - & - & - & - & - \\
\hline Canada & 15.77 & 2.37 & 13.41 & 12.48 & 1.13 & 11.35 & 9.09 & 23.65 \\
\hline UK & 9.58 & 15.44 & -5.86 & -6.79 & -1.38 & -5.41 & 20.31 & 36.82 \\
\hline Finland & 12.42 & -0.53 & 12.95 & 12.02 & 1.97 & 10.05 & 16.37 & -28.47 \\
\hline Denmark & 10.14 & 4.43 & 5.72 & 4.79 & 0.60 & 4.19 & 12.51 & -38.40 \\
\hline Germany & 18.00 & 12.48 & 5.52 & 4.59 & 3.62 & 0.98 & 78.72 & 22.10 \\
\hline Netherlands & 24.35 & 11.81 & 12.55 & 11.62 & -1.45 & 13.07 & -12.48 & -7.57 \\
\hline Belgium & 15.80 & 5.64 & 10.17 & 9.24 & 0.56 & 8.68 & 6.04 & 23.97 \\
\hline Austria & 30.42 & 2.82 & 27.60 & 26.67 & 3.88 & 22.79 & 14.54 & 6.29 \\
\hline Ireland & 21.78 & 8.05 & 13.74 & 12.81 & 3.13 & 9.68 & 24.46 & 19.34 \\
\hline France & 16.85 & 6.70 & 10.15 & 9.22 & 0.40 & 8.82 & 4.35 & -20.28 \\
\hline Italy & 26.09 & 3.68 & 22.41 & 21.49 & 1.88 & 19.61 & 8.74 & 17.56 \\
\hline Spain & 27.15 & 10.19 & 16.96 & 16.04 & 2.05 & 13.99 & 12.79 & 15.20 \\
\hline Portugal & 22.35 & -2.17 & 24.52 & 23.59 & 4.76 & 18.83 & 20.19 & 10.53 \\
\hline Greece & 24.67 & 7.78 & 16.89 & 15.97 & 3.12 & 12.84 & 19.57 & 29.85 \\
\hline
\end{tabular}

Notes. Wage bill shares for the US are computed as shares of previous-year annual earnings, for Canada they are computed as shares of current weekly earnings and for European countries they are computed are shares of current monthly earnings. See notes to Figure 1 for samples and source. Decomposition based on equations (7) and (8) in the text. 
Table 3

Further decomposition of triple differences in gender gaps

in wage bill shares $(\times 100)$ between each country and the US.

Three broad industries.

\begin{tabular}{|c|c|c|c|c|}
\hline & Total & $\begin{array}{c}\text { Primary, } \\
\text { Manuf. } \\
\& \\
\text { Construct. }\end{array}$ & Services & $\begin{array}{l}\text { Public } \\
\text { Admin. }\end{array}$ \\
\hline & 1 & 2 & 3 & 4 \\
\hline \multicolumn{5}{|c|}{ Between component } \\
\hline Canada & 1.13 & 0.05 & 1.15 & -0.06 \\
\hline UK & -1.38 & -1.55 & 0.50 & -0.33 \\
\hline Finland & 1.97 & -0.10 & 2.01 & 0.06 \\
\hline Denmark & 0.60 & -0.62 & 1.42 & -0.21 \\
\hline Germany & 3.62 & 1.66 & 1.92 & 0.04 \\
\hline Netherlands & -1.45 & -1.51 & -0.10 & 0.16 \\
\hline Belgium & 0.56 & -1.61 & 2.13 & 0.04 \\
\hline Austria & 3.40 & 2.40 & 0.65 & 0.35 \\
\hline Ireland & 3.13 & -0.12 & 2.86 & 0.39 \\
\hline France & 0.40 & -0.94 & 1.36 & -0.01 \\
\hline Italy & 1.88 & 0.36 & 0.88 & 0.64 \\
\hline Spain & 2.05 & 1.03 & 0.98 & 0.04 \\
\hline Portugal & 4.76 & 1.92 & 1.86 & 0.99 \\
\hline Greece & 3.12 & -0.70 & 3.30 & 0.53 \\
\hline \multicolumn{5}{|c|}{ Within component } \\
\hline Canada & 11.35 & 10.57 & 0.17 & 0.61 \\
\hline UK & -5.41 & -2.35 & -2.37 & -0.70 \\
\hline Finland & 10.05 & 5.95 & 4.17 & -0.06 \\
\hline Denmark & 4.19 & 1.94 & 2.23 & 0.02 \\
\hline Germany & 0.98 & 1.98 & -2.37 & 1.37 \\
\hline Netherlands & 13.07 & 8.43 & 2.77 & 1.87 \\
\hline Belgium & 8.68 & 2.46 & 4.85 & 1.37 \\
\hline Austria & 22.62 & 13.04 & 6.75 & 2.84 \\
\hline Ireland & 9.68 & 6.20 & 0.69 & 2.79 \\
\hline France & 8.82 & 4.74 & 2.89 & 1.19 \\
\hline Italy & 19.61 & 10.68 & 5.30 & 3.63 \\
\hline Spain & 13.99 & 3.99 & 8.60 & 1.40 \\
\hline Portugal & 18.83 & 7.03 & 7.41 & 4.39 \\
\hline Greece & 12.84 & 5.05 & 4.83 & 2.96 \\
\hline
\end{tabular}

Notes. Figures represent the contribution of each broad industry to the shift-share analysis reported in Table 4. The primary sector includes: agriculture, hunting, forestry and fishing; mining and quarrying; electricity, gas and water supply. 
Table 4

Further decomposition (II) of triple differences in gender gaps

in wage bill shares $(\times 100)$ between each country and the US.

Detailed service industries.

\begin{tabular}{|c|c|c|c|c|c|c|c|}
\hline & $\begin{array}{c}\text { Total } \\
\text { Services }\end{array}$ & Transport & Trade & Finance & Education & Health & Other \\
\hline & 1 & 2 & 3 & 4 & 5 & 6 & 7 \\
\hline \multicolumn{8}{|c|}{ Between component } \\
\hline Canada & 1.15 & -0.06 & -0.05 & 1.46 & 0.11 & -0.33 & 0.01 \\
\hline UK & 0.50 & 0.12 & 0.21 & -0.09 & 0.14 & 0.00 & 0.12 \\
\hline Finland & 2.01 & 0.69 & 0.15 & 1.07 & 0.08 & 0.05 & -0.02 \\
\hline Denmark & 1.42 & 0.08 & -0.38 & 1.31 & 0.02 & 0.44 & -0.03 \\
\hline Germany & 1.92 & 0.01 & 0.13 & 1.77 & -0.19 & 0.19 & 0.01 \\
\hline Netherlands & -0.10 & 0.56 & -0.28 & 0.23 & -0.01 & -0.67 & 0.07 \\
\hline Belgium & 2.13 & 0.24 & 0.04 & 0.77 & 1.11 & 0.05 & -0.09 \\
\hline Austria & 0.65 & 0.47 & 0.00 & 0.15 & -0.23 & 0.26 & 0.00 \\
\hline Ireland & 2.86 & 0.94 & -0.06 & 1.51 & 0.43 & 0.01 & 0.03 \\
\hline France & 1.36 & 0.34 & -0.05 & 0.77 & 0.13 & 0.00 & 0.17 \\
\hline Italy & 0.88 & 0.46 & -0.45 & 0.93 & 0.04 & -0.15 & 0.05 \\
\hline Spain & 0.98 & 0.29 & -0.10 & 0.68 & 0.18 & -0.06 & 0.00 \\
\hline Portugal & 1.86 & 0.13 & -0.02 & 0.75 & 0.70 & 0.13 & 0.16 \\
\hline Greece & 3.30 & 1.17 & -0.03 & 1.58 & 0.47 & 0.10 & 0.00 \\
\hline \multicolumn{8}{|c|}{ Within component } \\
\hline Canada & 0.17 & 2.39 & 1.81 & 0.39 & -1.20 & -4.20 & 0.99 \\
\hline UK & -2.37 & -0.62 & -1.36 & -0.06 & -0.10 & -0.15 & -0.09 \\
\hline Finland & 4.17 & 1.32 & -0.43 & 2.37 & -0.13 & 0.11 & 0.93 \\
\hline Denmark & 2.23 & -0.01 & 2.55 & -1.97 & -1.04 & 1.97 & 0.74 \\
\hline Germany & -2.37 & 1.16 & -0.20 & 1.21 & -1.55 & -2.98 & 0.00 \\
\hline Netherlands & 2.77 & 2.80 & 3.08 & 4.12 & -3.61 & -3.82 & 0.19 \\
\hline Belgium & 4.85 & 1.71 & 0.41 & 1.39 & 0.34 & 0.49 & 0.53 \\
\hline Austria & 6.75 & 3.47 & 0.89 & 6.53 & -0.56 & -4.41 & 0.82 \\
\hline Ireland & 0.69 & 2.40 & 0.96 & 0.75 & -0.86 & -2.82 & 0.27 \\
\hline France & 2.89 & 1.52 & 1.49 & 1.57 & -0.88 & -0.28 & -0.53 \\
\hline Italy & 5.30 & 3.20 & 2.68 & 4.04 & -3.04 & -2.79 & 1.21 \\
\hline Spain & 8.60 & 1.00 & 2.63 & 4.37 & -0.16 & 0.49 & 0.27 \\
\hline Portugal & 7.41 & 1.33 & 3.59 & 4.47 & 0.18 & -1.04 & -1.12 \\
\hline Greece & 4.83 & 1.40 & 2.29 & 1.90 & -0.68 & -0.77 & 0.69 \\
\hline
\end{tabular}

Notes. Figures represent the contribution of each 1-digit service industry to the shift-share analysis reported in Table 4. See main text for the exact definition of industries. 
Table 5

Shift share decomposition of differences hours shares (x100) over the period 1971-2001

\begin{tabular}{|c|c|c|c|c|c|c|c|c|}
\hline & & 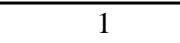 & 2 & 3 & 4 & 5 & 6 & 7 \\
\hline \multirow{2}{*}{ Country } & \multirow{2}{*}{ Year } & \multicolumn{2}{|c|}{ Gender gaps in Hours Shares } & \multirow{2}{*}{$\begin{array}{l}\text { Difference } \\
\text { (1)-(2) }\end{array}$} & \multirow{2}{*}{$\begin{array}{c}\text { Cross- } \\
\text { country } \\
\text { difference }\end{array}$} & \multirow{2}{*}{$\begin{array}{c}\text { Between } \\
\text { industry } \\
\text { component }\end{array}$} & \multirow{2}{*}{$\begin{array}{c}\text { Within } \\
\text { industry } \\
\text { component }\end{array}$} & \multirow{2}{*}{$\begin{array}{c}\text { Services } \\
\text { componen } \\
\text { of Between }\end{array}$} \\
\hline & & Unskilled & Skilled & & & & & \\
\hline \multirow[t]{4}{*}{ USA } & 1971 & 33.67 & 7.69 & 25.98 & - & . & . &. \\
\hline & 1981 & 19.82 & 9.1 & 10.72 & . & . & . & . \\
\hline & 1991 & 12.6 & 6.99 & 5.61 & . & . & . & . \\
\hline & 2001 & 10.55 & 5.19 & 5.36 & . & . & . & . \\
\hline \multirow[t]{4}{*}{ Canada } & 1971 & 38.35 & 4.28 & 34.07 & 8.09 & 2.66 & 5.43 & -0.09 \\
\hline & 1981 & 27.92 & 4.68 & 23.24 & 12.52 & 2.77 & 9.75 & 1.36 \\
\hline & 1991 & 19.37 & 3.89 & 15.49 & 9.87 & 2.78 & 7.09 & 1.23 \\
\hline & 2001 & 16.67 & 2.88 & 13.79 & 8.43 & 2.03 & 6.4 & 1.47 \\
\hline \multirow[t]{4}{*}{ UK } & 1971 & 16.82 & 0.92 & 15.9 & -10.08 & 5.63 & -15.71 & 2.45 \\
\hline & 1981 & 16.98 & 3.09 & 13.89 & 3.16 & 4.83 & -1.67 & 2.21 \\
\hline & 1991 & 8.54 & 3.72 & 4.82 & -0.79 & 3.71 & -4.5 & 1.4 \\
\hline & 2001 & 6.99 & 3.61 & 3.38 & -1.98 & 1.05 & -3.03 & 0.54 \\
\hline \multirow[t]{4}{*}{ Finland } & 1971 & 17.83 & 2.01 & 15.82 & -10.15 & 15.70 & -25.85 & 2.76 \\
\hline & 1981 & 11.67 & 2.16 & 9.51 & -1.22 & 10.66 & -11.88 & 3.16 \\
\hline & 1991 & 5.53 & 0.40 & 5.13 & -0.49 & 6.53 & -7.02 & 1.72 \\
\hline & 2001 & 8.84 & -2.06 & 10.90 & 5.54 & 4.44 & 1.10 & 1.08 \\
\hline \multirow[t]{3}{*}{ Denmark } & 1981 & 12.80 & 1.74 & 11.05 & 0.33 & -2.45 & 2.77 & -3.08 \\
\hline & 1991 & 7.96 & 1.81 & 6.15 & 0.54 & -1.86 & 2.40 & -2.75 \\
\hline & 2001 & 8.66 & 1.56 & 7.11 & 1.74 & -1.42 & 3.17 & -2.09 \\
\hline \multirow[t]{2}{*}{ Germany } & 1991 & 11.68 & 3.08 & 8.60 & 2.98 & 7.65 & -4.67 & 3.00 \\
\hline & 2001 & 8.34 & 3.00 & 5.34 & -0.02 & 3.12 & -3.14 & 0.83 \\
\hline \multirow[t]{3}{*}{ Netherlands } & 1981 & 47.26 & 3.48 & 43.78 & 33.06 & 0.89 & 32.16 & -0.84 \\
\hline & 1991 & 37.46 & 4.18 & 33.29 & 27.67 & 1.82 & 25.85 & 0.38 \\
\hline & 2001 & 28.82 & 3.55 & 25.26 & 19.90 & 0.58 & 19.32 & 0.02 \\
\hline \multirow[t]{3}{*}{ Belgium } & 1981 & 26.45 & 3.04 & 23.41 & 12.69 & 3.94 & 8.74 & 2.15 \\
\hline & 1991 & 19.26 & 3.46 & 15.81 & 10.19 & 3.83 & 6.36 & 2.02 \\
\hline & 2001 & 12.92 & 3.33 & 9.60 & 4.24 & 1.20 & 3.03 & 1.18 \\
\hline \multirow[t]{3}{*}{ Austria } & 1981 & 17.12 & 1.97 & 15.15 & 4.43 & 4.88 & -0.45 & 2.84 \\
\hline & 1991 & 15.41 & 2.71 & 12.70 & 7.08 & 2.95 & 4.13 & 2.10 \\
\hline & 2001 & 14.96 & 1.81 & 13.16 & 7.79 & 2.32 & 5.48 & 1.20 \\
\hline \multirow[t]{3}{*}{ France } & 1981 & 11.24 & 1.14 & 10.10 & -0.62 & -3.04 & 2.41 & 3.05 \\
\hline & 1991 & 8.20 & 1.06 & 7.15 & 1.53 & -0.02 & 1.55 & 4.46 \\
\hline & 2001 & 6.62 & 0.74 & 5.87 & 0.51 & -2.94 & 3.45 & 2.29 \\
\hline \multirow[t]{4}{*}{ Italy } & 1971 & 36.94 & 1.56 & 35.37 & 9.40 & 11.05 & -1.65 & 0.16 \\
\hline & 1981 & 34.09 & 1.85 & 32.24 & 21.52 & 8.81 & 12.71 & 2.76 \\
\hline & 1991 & 26.58 & 1.94 & 24.64 & 19.03 & 6.18 & 12.84 & 2.86 \\
\hline & 2001 & 21.69 & 1.67 & 20.02 & 14.66 & 4.49 & 10.17 & 1.84 \\
\hline \multirow[t]{3}{*}{ Spain } & 1981 & 40.21 & 2.50 & 37.71 & 26.99 & 9.26 & 17.73 & 1.49 \\
\hline & 1991 & 32.61 & 1.86 & 30.75 & 25.13 & 8.69 & 16.44 & 2.10 \\
\hline & 2001 & 25.43 & 1.00 & 24.43 & 19.06 & 8.86 & 10.21 & 2.27 \\
\hline Portugal & 1991 & 18.54 & 0.28 & 18.26 & 12.65 & 11.94 & 0.71 & 3.40 \\
\hline & 2001 & 12.54 & -1.88 & 14.42 & 9.06 & 8.82 & 0.24 & 2.95 \\
\hline Greece & 1971 & 54.10 & 4.28 & 49.82 & 23.84 & 10.75 & 13.26 & 3.98 \\
\hline & 1981 & 41.03 & 4.86 & 36.16 & 25.44 & 11.37 & 14.07 & 4.32 \\
\hline & 1991 & 30.04 & 4.01 & 26.03 & 20.41 & 6.45 & 13.97 & 3.20 \\
\hline & 2001 & 25.38 & 1.55 & 23.83 & 18.47 & 6.34 & 12.14 & 2.64 \\
\hline
\end{tabular}

Data Sources: France: Enquete Emploi. Greece and Portugal: IPUMS-International. All other countries: EU_KLEMS. See Appendix B for more details on samples and sources. 
Table 6

Model-based decomposition of the gender bias in labor demand $(\times 100)$

\begin{tabular}{|c|c|c|c|c|c|c|}
\hline & \multicolumn{3}{|c|}{$\sigma=1$} & \multicolumn{3}{|c|}{$\sigma=2.5$} \\
\hline & 1 & 2 & 3 & 4 & 5 & 6 \\
\hline & $\begin{array}{c}\text { Triple } \\
\text { diff in } \\
\text { labor } \\
\text { demand } \\
\end{array}$ & $\begin{array}{c}\text { Between } \\
\text { industry } \\
\text { compt. }\end{array}$ & $\begin{array}{c}(2) /(1) \\
\mathrm{x} 100\end{array}$ & $\begin{array}{l}\text { Triple diff } \\
\text { in labor } \\
\text { demand }\end{array}$ & $\begin{array}{c}\text { Between } \\
\text { industry } \\
\text { compt. }\end{array}$ & $\begin{array}{c}(2) /(1) \\
\mathrm{x} 100\end{array}$ \\
\hline Canada & 17.14 & 4.88 & 28.46 & 32.19 & 12.20 & 37.89 \\
\hline UK & -26.53 & -3.75 & 14.12 & -20.29 & -9.37 & 46.15 \\
\hline Finland & 44.76 & 7.32 & 16.34 & 39.07 & 18.29 & 46.81 \\
\hline Denmark & 15.23 & 3.62 & 23.74 & 9.76 & 9.04 & 92.60 \\
\hline Germany & -34.99 & 11.12 & -31.79 & -42.45 & 27.81 & -65.51 \\
\hline Netherlands & -9.75 & -4.37 & 44.83 & -19.40 & -10.93 & 56.36 \\
\hline Belgium & 43.79 & 5.89 & 13.45 & 42.68 & 14.72 & 34.50 \\
\hline Austria & 26.09 & 11.91 & 45.66 & 16.42 & 29.78 & 181.40 \\
\hline Ireland & 16.87 & 14.66 & 86.92 & 35.60 & 36.65 & 102.98 \\
\hline France & 19.09 & 2.31 & 12.08 & 7.22 & 5.77 & 79.88 \\
\hline Italy & 12.31 & 8.11 & 65.91 & 14.69 & 20.28 & 138.02 \\
\hline Spain & 52.51 & 7.66 & 14.59 & 50.93 & 19.15 & 37.61 \\
\hline Portugal & 71.54 & 18.76 & 26.22 & 72.33 & 46.89 & 64.83 \\
\hline Greece & 49.12 & 13.44 & 27.36 & 58.04 & 33.61 & 57.90 \\
\hline
\end{tabular}

Notes. Columns 1 reports triple differences in labor demand for the Cobb-Douglas case (see equation (11)), column 2 reports their between-industry component (see equation (12)), and column 3 reports the proportion of the total explained by the between-industry component. Column 4 reports triple differences in labor demand for the CES case with $\sigma=2.5$ (see equation (14)), column 5 reports their between-industry component (see equation (32)), and column 6 reports the proportion of the total explained by the between-industry component. 


\section{Appendix Tables}

Table A1

Distribution of Population by Educational Attainment

\begin{tabular}{lcccccc}
\hline & \multicolumn{3}{c}{ Males } & & \multicolumn{3}{c}{ Females } \\
\hline US & Educ. $=1$ & Educ. $=2$ & Educ. $=3$ & Educ. $=1$ & Educ. $=2$ & Educ. $=3$ \\
Canada & 0.065 & 0.233 & 0.166 & 0.068 & 0.275 & 0.193 \\
UK & 0.095 & 0.297 & 0.076 & 0.093 & 0.349 & 0.089 \\
Finland & 0.166 & 0.088 & 0.191 & 0.275 & 0.105 & 0.176 \\
Denmark & 0.112 & 0.245 & 0.140 & 0.109 & 0.246 & 0.147 \\
Germany & 0.093 & 0.217 & 0.158 & 0.092 & 0.193 & 0.247 \\
Netherlands & 0.085 & 0.215 & 0.190 & 0.095 & 0.192 & 0.224 \\
Belgium & 0.084 & 0.274 & 0.121 & 0.121 & 0.308 & 0.093 \\
Austria & 0.111 & 0.242 & 0.109 & 0.158 & 0.280 & 0.099 \\
Ireland & 0.124 & 0.161 & 0.180 & 0.143 & 0.170 & 0.223 \\
France & 0.060 & 0.382 & 0.040 & 0.136 & 0.333 & 0.050 \\
Italy & 0.194 & 0.154 & 0.089 & 0.241 & 0.234 & 0.088 \\
Spain & 0.140 & 0.211 & 0.120 & 0.180 & 0.203 & 0.147 \\
Portugal & 0.212 & 0.187 & 0.048 & 0.282 & 0.220 & 0.050 \\
Greece & 0.259 & 0.088 & 0.115 & 0.322 & 0.091 & 0.124 \\
\hline & 0.370 & 0.064 & 0.033 & 0.413 & 0.067 & 0.053 \\
\hline
\end{tabular}

Notes. Educ. $=1$ includes individuals with less than upper secondary education; Educ. $=2$ includes individuals who have completed upper secondary education; Educ. $=3$ includes individuals who have completed college education or above. See notes to Fig. 1 for samples and sources.

Table A2

Wage bill shares of four demographic groups

\begin{tabular}{|c|c|c|c|c|}
\hline & \multicolumn{2}{|c|}{ No college degree } & \multicolumn{2}{|c|}{ College degree } \\
\hline & Males & Females & Males & Females \\
\hline US & 0.297 & 0.184 & 0.311 & 0.207 \\
\hline Canada & 0.452 & 0.139 & 0.294 & 0.115 \\
\hline UK & 0.287 & 0.186 & 0.344 & 0.183 \\
\hline Finland & 0.309 & 0.189 & 0.255 & 0.247 \\
\hline Denmark & 0.310 & 0.202 & 0.268 & 0.220 \\
\hline Germany & 0.436 & 0.248 & 0.221 & 0.095 \\
\hline Netherlands & 0.469 & 0.212 & 0.222 & 0.096 \\
\hline Belgium & 0.309 & 0.145 & 0.304 & 0.242 \\
\hline Austria & 0.587 & 0.274 & 0.084 & 0.055 \\
\hline Ireland & 0.438 & 0.209 & 0.219 & 0.134 \\
\hline France & 0.384 & 0.210 & 0.237 & 0.169 \\
\hline Italy & 0.550 & 0.285 & 0.101 & 0.064 \\
\hline Spain & 0.416 & 0.141 & 0.277 & 0.167 \\
\hline Portugal & 0.495 & 0.264 & 0.114 & 0.128 \\
\hline Greece & 0.422 & 0.157 & 0.252 & 0.169 \\
\hline
\end{tabular}

See notes to Figure 1 for samples and sources. 
Table A3

Wage Bill Shares of Four Demographic Groups by Sector

\begin{tabular}{|c|c|c|c|c|c|c|c|c|c|c|}
\hline & $\begin{array}{c}\text { Primary } \\
\& \\
\text { Utilities }\end{array}$ & Manuf. & Constr. & $\begin{array}{l}\text { Transp., } \\
\text { Storage, } \\
\text { Comm. }\end{array}$ & $\begin{array}{c}\text { Trade, } \\
\text { Hotels, } \\
\text { Rest. }\end{array}$ & $\begin{array}{c}\text { Finance, } \\
\text { Insuranc } \\
\text { e, } \\
\text { Real Est. }\end{array}$ & Educ. & Health & $\begin{array}{c}\text { Other } \\
\text { Services }\end{array}$ & $\begin{array}{l}\text { Public } \\
\text { Admin. }\end{array}$ \\
\hline & \multicolumn{10}{|c|}{ USA } \\
\hline MU & 0.539 & 0.414 & 0.718 & 0.456 & 0.375 & 0.164 & 0.056 & 0.057 & 0.198 & 0.282 \\
\hline FU & 0.095 & 0.157 & 0.054 & 0.150 & 0.260 & 0.190 & 0.138 & 0.254 & 0.260 & 0.188 \\
\hline MS & 0.288 & 0.332 & 0.197 & 0.285 & 0.252 & 0.427 & 0.281 & 0.243 & 0.280 & 0.343 \\
\hline FS & 0.078 & 0.097 & 0.031 & 0.108 & 0.114 & 0.219 & 0.525 & 0.446 & 0.261 & 0.186 \\
\hline \multirow[t]{2}{*}{$\begin{array}{l}\text { Sector } \\
\text { Share }\end{array}$} & 0.039 & 0.189 & 0.060 & 0.059 & 0.150 & 0.193 & 0.093 & 0.099 & 0.045 & 0.073 \\
\hline & \multicolumn{10}{|c|}{ Canada } \\
\hline $\mathrm{MU}$ & 0.737 & 0.688 & 0.868 & 0.752 & 0.504 & 0.274 & 0.102 & 0.114 & 0.444 & 0.373 \\
\hline FU & 0.114 & 0.175 & 0.072 & 0.169 & 0.375 & 0.384 & 0.187 & 0.628 & 0.312 & 0.288 \\
\hline MS & 0.120 & 0.109 & 0.051 & 0.061 & 0.074 & 0.221 & 0.292 & 0.065 & 0.141 & 0.208 \\
\hline FS & 0.029 & 0.028 & 0.009 & 0.017 & 0.047 & 0.121 & 0.418 & 0.193 & 0.103 & 0.132 \\
\hline $\begin{array}{l}\text { Sector } \\
\text { Share }\end{array}$ & 0.067 & 0.182 & 0.046 & 0.057 & 0.138 & 0.128 & 0.104 & 0.116 & 0.068 & 0.094 \\
\hline & \multicolumn{10}{|c|}{ UK } \\
\hline $\mathrm{MU}$ & 0.586 & 0.441 & 0.519 & 0.470 & 0.345 & 0.216 & 0.027 & 0.064 & 0.241 & 0.252 \\
\hline FU & 0.113 & 0.145 & 0.045 & 0.148 & 0.299 & 0.170 & 0.114 & 0.328 & 0.260 & 0.202 \\
\hline MS & 0.236 & 0.353 & 0.411 & 0.332 & 0.263 & 0.449 & 0.311 & 0.177 & 0.286 & 0.370 \\
\hline FS & 0.065 & 0.060 & 0.025 & 0.051 & 0.093 & 0.165 & 0.548 & 0.430 & 0.214 & 0.176 \\
\hline $\begin{array}{l}\text { Sector } \\
\text { Share }\end{array}$ & 0.005 & 0.230 & 0.037 & 0.073 & 0.121 & 0.197 & 0.100 & 0.099 & 0.032 & 0.106 \\
\hline & \multicolumn{10}{|c|}{ Finland } \\
\hline $\mathrm{MU}$ & 0.528 & 0.507 & 0.845 & 0.551 & 0.294 & 0.193 & 0.059 & 0.035 & 0.194 & 0.174 \\
\hline $\mathrm{FU}$ & 0.164 & 0.155 & 0.026 & 0.116 & 0.288 & 0.179 & 0.111 & 0.377 & 0.164 & 0.145 \\
\hline MS & 0.219 & 0.226 & 0.111 & 0.230 & 0.240 & 0.366 & 0.314 & 0.118 & 0.264 & 0.392 \\
\hline FS & 0.089 & 0.112 & 0.018 & 0.103 & 0.177 & 0.262 & 0.517 & 0.470 & 0.378 & 0.289 \\
\hline $\begin{array}{l}\text { Sector } \\
\text { Share }\end{array}$ & 0.020 & 0.240 & 0.055 & 0.089 & 0.113 & 0.127 & 0.098 & 0.156 & 0.037 & 0.065 \\
\hline & \multicolumn{10}{|c|}{ Denmark } \\
\hline MU & 0.656 & 0.484 & 0.665 & 0.498 & 0.477 & 0.168 & 0.058 & 0.068 & 0.305 & 0.192 \\
\hline $\mathrm{FU}$ & 0.134 & 0.185 & 0.061 & 0.206 & 0.258 & 0.183 & 0.095 & 0.300 & 0.230 & 0.252 \\
\hline MS & 0.191 & 0.246 & 0.238 & 0.230 & 0.152 & 0.493 & 0.379 & 0.120 & 0.246 & 0.278 \\
\hline FS & 0.019 & 0.085 & 0.036 & 0.066 & 0.113 & 0.156 & 0.468 & 0.513 & 0.219 & 0.278 \\
\hline $\begin{array}{l}\text { Sector } \\
\text { Share }\end{array}$ & 0.014 & 0.190 & 0.063 & 0.064 & 0.101 & 0.149 & 0.096 & 0.151 & 0.067 & 0.106 \\
\hline & \multicolumn{10}{|c|}{ Germany } \\
\hline $\mathrm{MU}$ & 0.471 & 0.530 & 0.720 & 0.629 & 0.420 & 0.340 & 0.051 & 0.132 & 0.339 & 0.413 \\
\hline $\mathrm{FU}$ & 0.197 & 0.170 & 0.058 & 0.169 & 0.384 & 0.312 & 0.151 & 0.528 & 0.277 & 0.256 \\
\hline MS & 0.244 & 0.273 & 0.190 & 0.165 & 0.127 & 0.261 & 0.371 & 0.123 & 0.258 & 0.197 \\
\hline FS & 0.089 & 0.027 & 0.032 & 0.037 & 0.069 & 0.087 & 0.428 & 0.217 & 0.126 & 0.134 \\
\hline $\begin{array}{l}\text { Sector } \\
\text { Share }\end{array}$ & 0.010 & 0.338 & 0.086 & 0.060 & 0.107 & 0.102 & 0.063 & 0.084 & 0.043 & 0.108 \\
\hline & \multicolumn{10}{|c|}{ Netherlands } \\
\hline MU & 0.658 & 0.665 & 0.850 & 0.725 & 0.569 & 0.409 & 0.099 & 0.145 & 0.375 & 0.478 \\
\hline $\mathrm{FU}$ & 0.225 & 0.131 & 0.076 & 0.134 & 0.273 & 0.213 & 0.118 & 0.485 & 0.235 & 0.172 \\
\hline MS & 0.085 & 0.167 & 0.063 & 0.094 & 0.123 & 0.292 & 0.490 & 0.170 & 0.280 & 0.265 \\
\hline FS & 0.032 & 0.037 & 0.011 & 0.047 & 0.034 & 0.086 & 0.292 & 0.200 & 0.110 & 0.085 \\
\hline $\begin{array}{l}\text { Sector } \\
\text { Share }\end{array}$ & 0.010 & 0.165 & 0.058 & 0.076 & 0.119 & 0.174 & 0.097 & 0.143 & 0.033 & 0.125 \\
\hline
\end{tabular}


Table A3 (continued)

Wage Bill Shares of Four Demographic Groups by Sector

\begin{tabular}{|c|c|c|c|c|c|c|c|c|c|c|}
\hline & $\begin{array}{c}\text { Primary } \\
\& \\
\text { Utilities }\end{array}$ & Manuf. & Constr. & $\begin{array}{l}\text { Transp., } \\
\text { Storage, } \\
\text { Comm. }\end{array}$ & $\begin{array}{c}\text { Trade, } \\
\text { Hotels, } \\
\text { Rest. }\end{array}$ & $\begin{array}{c}\text { Finance, } \\
\text { Insuranc } \\
\text { e, } \\
\text { Real Est. }\end{array}$ & Educ. & Health & $\begin{array}{c}\text { Other } \\
\text { Services }\end{array}$ & $\begin{array}{l}\text { Public } \\
\text { Admin. }\end{array}$ \\
\hline & \multicolumn{10}{|c|}{ Belgium } \\
\hline MU & 0.463 & 0.485 & 0.686 & 0.623 & 0.378 & 0.197 & 0.037 & 0.053 & 0.303 & 0.393 \\
\hline $\mathrm{FU}$ & 0.063 & 0.119 & 0.024 & 0.088 & 0.282 & 0.137 & 0.074 & 0.286 & 0.192 & 0.168 \\
\hline MS & 0.333 & 0.311 & 0.237 & 0.219 & 0.208 & 0.442 & 0.333 & 0.190 & 0.303 & 0.287 \\
\hline FS & 0.141 & 0.086 & 0.053 & 0.071 & 0.132 & 0.225 & 0.556 & 0.472 & 0.202 & 0.152 \\
\hline \multirow[t]{2}{*}{ Sector Share } & 0.006 & 0.217 & 0.040 & 0.067 & 0.070 & 0.155 & 0.157 & 0.118 & 0.070 & 0.100 \\
\hline & \multicolumn{10}{|c|}{ Austria } \\
\hline MU & 0.697 & 0.744 & 0.901 & 0.833 & 0.513 & 0.551 & 0.120 & 0.165 & 0.474 & 0.598 \\
\hline $\mathrm{FU}$ & 0.160 & 0.179 & 0.073 & 0.138 & 0.454 & 0.285 & 0.178 & 0.662 & 0.354 & 0.257 \\
\hline MS & 0.143 & 0.069 & 0.026 & 0.029 & 0.025 & 0.113 & 0.274 & 0.072 & 0.099 & 0.122 \\
\hline FS & 0.000 & 0.008 & 0.000 & 0.000 & 0.007 & 0.051 & 0.428 & 0.101 & 0.073 & 0.023 \\
\hline \multirow[t]{2}{*}{ Sector Share } & 0.011 & 0.245 & 0.096 & 0.071 & 0.146 & 0.107 & 0.075 & 0.087 & 0.050 & 0.112 \\
\hline & \multicolumn{10}{|c|}{ Ireland } \\
\hline MU & 0.644 & 0.578 & 0.850 & 0.689 & 0.477 & 0.264 & 0.046 & 0.138 & 0.372 & 0.526 \\
\hline $\mathrm{FU}$ & 0.043 & 0.183 & 0.036 & 0.110 & 0.350 & 0.267 & 0.062 & 0.538 & 0.327 & 0.147 \\
\hline MS & 0.305 & 0.189 & 0.108 & 0.166 & 0.125 & 0.326 & 0.394 & 0.102 & 0.179 & 0.243 \\
\hline FS & 0.009 & 0.049 & 0.005 & 0.035 & 0.048 & 0.142 & 0.499 & 0.221 & 0.123 & 0.084 \\
\hline \multirow[t]{2}{*}{ Sector Share } & 0.017 & 0.212 & 0.063 & 0.092 & 0.108 & 0.122 & 0.127 & 0.098 & 0.038 & 0.123 \\
\hline & \multicolumn{10}{|c|}{ France } \\
\hline MU & 0.639 & 0.525 & 0.790 & 0.581 & 0.450 & 0.250 & 0.076 & 0.129 & 0.187 & 0.368 \\
\hline $\mathrm{FU}$ & 0.241 & 0.151 & 0.048 & 0.136 & 0.269 & 0.198 & 0.144 & 0.374 & 0.369 & 0.272 \\
\hline MS & 0.094 & 0.250 & 0.123 & 0.196 & 0.190 & 0.382 & 0.316 & 0.139 & 0.237 & 0.208 \\
\hline FS & 0.026 & 0.074 & 0.039 & 0.087 & 0.091 & 0.170 & 0.464 & 0.358 & 0.208 & 0.151 \\
\hline \multirow[t]{2}{*}{ Sector Share } & 0.007 & 0.225 & 0.053 & 0.069 & 0.132 & 0.155 & 0.107 & 0.102 & 0.032 & 0.119 \\
\hline & \multicolumn{10}{|c|}{ Italy } \\
\hline MU & 0.705 & 0.680 & 0.909 & 0.800 & 0.578 & 0.478 & 0.145 & 0.277 & 0.540 & 0.599 \\
\hline $\mathrm{FU}$ & 0.243 & 0.234 & 0.044 & 0.148 & 0.375 & 0.294 & 0.403 & 0.420 & 0.364 & 0.252 \\
\hline MS & 0.046 & 0.065 & 0.042 & 0.043 & 0.026 & 0.184 & 0.163 & 0.209 & 0.063 & 0.099 \\
\hline FS & 0.005 & 0.020 & 0.006 & 0.008 & 0.020 & 0.044 & 0.289 & 0.094 & 0.033 & 0.050 \\
\hline \multirow[t]{2}{*}{ Sector Share } & 0.026 & 0.246 & 0.054 & 0.071 & 0.097 & 0.093 & 0.114 & 0.111 & 0.060 & 0.129 \\
\hline & \multicolumn{10}{|c|}{ Spain } \\
\hline MU & 0.745 & 0.528 & 0.786 & 0.536 & 0.513 & 0.358 & 0.028 & 0.080 & 0.367 & 0.326 \\
\hline $\mathrm{FU}$ & 0.105 & 0.122 & 0.026 & 0.082 & 0.257 & 0.168 & 0.064 & 0.188 & 0.338 & 0.116 \\
\hline MS & 0.134 & 0.311 & 0.170 & 0.278 & 0.162 & 0.310 & 0.362 & 0.282 & 0.171 & 0.342 \\
\hline FS & 0.017 & 0.040 & 0.019 & 0.104 & 0.068 & 0.163 & 0.546 & 0.450 & 0.123 & 0.216 \\
\hline \multirow[t]{2}{*}{ Sector Share } & 0.022 & 0.219 & 0.086 & 0.073 & 0.135 & 0.123 & 0.105 & 0.079 & 0.045 & 0.113 \\
\hline & \multicolumn{10}{|c|}{ Portugal } \\
\hline MU & 0.705 & 0.599 & 0.907 & 0.622 & 0.594 & 0.427 & 0.081 & 0.083 & 0.231 & 0.584 \\
\hline $\mathrm{FU}$ & 0.277 & 0.314 & 0.048 & 0.174 & 0.341 & 0.196 & 0.237 & 0.433 & 0.572 & 0.248 \\
\hline MS & 0.011 & 0.068 & 0.038 & 0.155 & 0.051 & 0.272 & 0.174 & 0.124 & 0.102 & 0.083 \\
\hline FS & 0.007 & 0.020 & 0.007 & 0.050 & 0.014 & 0.105 & 0.508 & 0.360 & 0.095 & 0.084 \\
\hline \multirow[t]{2}{*}{ Sector Share } & 0.028 & 0.164 & 0.099 & 0.065 & 0.148 & 0.105 & 0.135 & 0.075 & 0.038 & 0.145 \\
\hline & \multicolumn{10}{|c|}{ Greece } \\
\hline MU & 0.707 & 0.516 & 0.847 & 0.618 & 0.459 & 0.216 & 0.024 & 0.124 & 0.383 & 0.467 \\
\hline $\mathrm{FU}$ & 0.225 & 0.218 & 0.022 & 0.062 & 0.270 & 0.203 & 0.045 & 0.249 & 0.238 & 0.137 \\
\hline MS & 0.037 & 0.186 & 0.115 & 0.288 & 0.164 & 0.350 & 0.403 & 0.294 & 0.218 & 0.262 \\
\hline FS & 0.030 & 0.080 & 0.017 & 0.032 & 0.107 & 0.231 & 0.527 & 0.333 & 0.161 & 0.135 \\
\hline Sector Share & 0.008 & 0.170 & 0.070 & 0.114 & 0.145 & 0.100 & 0.129 & 0.074 & 0.038 & 0.151 \\
\hline
\end{tabular}

Notes. $\mathrm{MU}=$ unskilled males, $\mathrm{FU}=$ unskilled females, $\mathrm{MS}=$ skilled males, FS= skilled females, where Unskilled= No College Degree $($ educ=1+2), Skilled= College Degree (educ=3). See notes to Figure 1 for samples and sources. 